\title{
In vitro effekte van 2-metoksiëstradiol op selgetalle, morfologie en geenuitdrukking in 'n borsepiteelkarsinoomsellyn
}

\author{
J Jansen VAN VuUren ${ }^{1}$ \& AM Joubert \\ Departement Fisiologie, Universiteit van Pretoria, Posbus 2034, Pretoria, Suid-Afrika, 0001 \\ Department of Physiology, University of Pretoria, P.O. Box 2034, Pretoria, South Africa, 0001 \\ jana_jvv@hotmail.com; annie.joubert@up.ac.za
}

\section{In vitro effects of 2-methoxyestradiol on cell numbers, morphology and gene expression in a breast adenocarcinoma cell line}

The aim of this study was to investigate the in vitro effects of 2-methoxyestradiol (2ME2) on a breast adenocarcinoma cell line (MCF-7). Spectrophotometry, microscopy and flow cytometry were used to determine the effects of $2 M E 2$ on cell growth, metabolic activity and morphology. These experiments demonstrated that 2ME2 inhibits growth and causes apoptosis in the MCF-7 cell line.

'n Endogene estrogeenmetaboliet 2-Metoksi ${ }_{s}$ stradiol (2ME2) wat anti-angiogenese en anti-mitotiese effekte in vitro en in vivo uitoefen, teiken ook aktief-prolifererende selle en speel 'n belangrike rol in die induksie van apoptose, veral in selle wat karsinogeniese eienskappe toon. As gevolg hiervan word 2ME2 bestempel as 'n belowende antitumor-agent in vergelyking met konvensionele chemoterapeutiese behandelinge. Aangesien die aksie-meganisme van 2ME2 in normale versus kankerselle nog nie opgeklaar is nie, was die doel van hierdie studie om die in vitro effekte van 2ME2 op selgetalle, morfologie en geenuitdrukking in 'n borsepiteelkarsinoomsellyn (MCF-7) te ondersoek. Dosis- en tydsafhanklike studies is uitgevoer ten einde die 2ME2 konsentrasie te bepaal wat 50\% inhibisie van selgroei bewerkstellig, asook optimale blootstellingstye. Invloed op selgroei en metaboliese aktiwiteite is spektrofotometries ondersoek deur gebruik te maak van kristalviolet as 'n DNS-kleurmiddel en 3-[4,5 dimetieltiazol-2-iel]-2,5-difeniel tetrasoliumbromied, respektiewelik. Die invloed van 2ME2 op morfologie is met behulp van ligmikroskopie en fluoressensiemikroskopie bepaal na hematoksilien en eosienkleuring, asook propidiumjodied en Hoechst 33342 kleurstowwe te gebruik na 24 uur blootstelling aan 2ME2. Vloeisitometrie is gebruik om die invloed op selsiklusprogressie en apoptose-induksie te ondersoek. 'n Totaal van $10^{-6} \mathrm{M}$ 2ME2 was verantwoordelik vir 50\% inhibisie van selgroei en die optimale blootstellingstyd is vasgestel as $24 \mathrm{~h}$. Hematoksilien en eosienkleuring het getoon dat die kontrole geen negatiewe effek op die morfologie van die MCF-7 selle gehad het nie. Die 2ME2-behandelde MCF-7 selle het duidelike eienskappe van apoptose getoon. Hierdie eienskappe sluit abnormale metafase selle, membraan-uitstulpings en apoptotiese liggaampies in. Propidiumjodied en Hoechst 33342 kleuring het die resultate wat met ligmikroskopie verkry is, bevestig. Membraan-uitstulpings en apoptotiese liggaampies is ook met dié kleuringstegniek in die 2ME2-behandelde selle waargeneem. Hierdie verskynsels is nie waargeneem in die kontroles wat die oplosmiddel vir $2 \mathrm{ME2}$ bevat het nie. Vloeisitometriese analise met Annexin V het gedui op die teenwoordigheid van $3.8 \%$ selle in vroeë apoptose na 24 uur blootstelling aan $10^{-6} \mathrm{M} 2 \mathrm{ME} 2$ in vergelyking met die $0.5 \%$ in kontroleselle. Hierdie studie dui aan dat 2ME2 wel groei geïnhibeer en apoptose geïnduseer het in die MCF-7 borskankersellyn. Vervolgens sal Agilent se menslike 1A Oligo Microarray skyfies met 20,173 bekende menslike 60-mer oligonukleotiedpeilers gebruik word om die invloed van 2ME2 op die 
geenuitdrukking in die kankerselle te bestudeer. Die studie sal 'n bydrae lewer tot die ontrafeling van die aksie-meganisme van 2ME2 deur seintransduksie en molekulêre meganismes geassosieer met 2ME2, in kankerselle te identifiseer.

\section{Aspekte van die voedingsbiologie van Lamproglena}

JJ Moll \& A Avenant-Oldewage

Departement Dierkunde, Universiteit van Johannesburg, Posbus 524, Aucklandpark, 2006

Department of Zoology, University of Johannesburg, P.O. Box 542, Auckland Park, 2006

januscham@yahoo.com; aoldewage@uj.ac.za

Aspects of the feeding biology of Lamproglena

Lamproglena clariae is a gill parasite of Clarias gariepinus. The digestive tract and mouthpart's morphology was studied from specimens collected from the Vaal Dam. The tract consists of a fore, mid-, and hindgut. The morphology indicates that it is able to suck blood.

Lamproglena clariae-individue is bekende kieuparasiete van Clarias gariepinus-eksemplare en gebruik hul maksillae en mandibels om vas te heg aan die kieue van hul gasheer. Dit word algemeen aanvaar dat die verkryging van voedsels net die maksillae en maksillipede betrek. Onsekerheid oor die weefseltipe waarop eksemplare van Lamproglena voed, bestaan. Bloed is nooit in die spysverteringstelsel van eksemplare van L. monodi aanwesig nie maar in die geval van L. clariae en L. barbicola-individue is die spysverteringstelsel met bloed gevul. 'n Studie om die morfologie van die spysverteringstelsel en die monddele deur middel van lig- en skandeerelektronmikroskopie te bestudeer, is aangepak. Lamproglena clariae-individue is versamel van C. gariepinus-eksemplare in die Vaaldam, nadat die visse gedood en die kieue verwyder is. Die eksemplare is in 'n ys-asynformaldehiedalkoholoplossing gefikseer en gepreserveer in $70 \%$ etanol voordat dit gedehidreer en in hars ingebed is. Seriesneë is gekleur en 'n grafiese rekonstruksie van die spysverteringstelsel het gevolg. Die spysverteringstelsel bestaan uit 'n voor-, middel- en agterderm. Die esofagus is uitgevoer met selle wat bedek is met kutikula en dit word omring deur' $n$ spierlaag. Die esofagus is verleng tot ' $\mathrm{n}$ tregtervormige struktuur wat tot binne-in die middelderm verloop. Die middelderm bestaan uit drie dele, naamlik die anterior-, mediane en posteriorsones wat gekenmerk word deur verskillende epiteellae. Die agterderm is 'n eenvoudige, gekutiniseerde buis. Die morfologie dui daarop dat eksemplare van $L$. clariae in staat is om bloed te suig. Die struktuur van die patologieveroorsakende monddele steun die aanname. 


\section{In vitro effek van 2-metoksiëstradiol op selgetalle, morfologie, selsiklusprogressie en geenekspressie in 'n normale epiteelbors-sellyn}

\section{Grant \& AM JouberT}

Departement Fisiologie, Universiteit van Pretoria, Posbus 2034, Pretoria, 0001, Suid-Afrika Department of Physiology, University of Pretoria, P.O. Box 2034, Pretoria, 0001, South Africa jimgrant@iafrica.com; annie.joubert@up.ac.za

In vitro effects of 2-methoxyestradiol on cell number, morphology, cell cycle progression and gene expression in a normal breast cell line

2-Methoxyestradiol (2ME2) (1 micromolar) inhibited growth in a normal breast cell line. Light and fluorescence microscopy revealed apoptotic morphology. Pilot microarray studies will contribute to the unravelling of $2 \mathrm{ME}$ 's action mechanism in normal cells.

Ten spyte van die vordering in die diagnose en behandeling van borskanker, eis hierdie siekte jaarliks steeds die lewens van duisende vroue wêreldwyd. Navorsing het getoon dat 2metoksiëstradiol (2ME2), 'n 17b-estradiol metaboliet, angiogenese inhibeer, antimitotiese eienskappe het en ook mitotiese spindels en selsiklusprogressie beïnvloed. Toediening van 2ME2 veroorsaak mitotiese opeenhoping en abnormale mitotiese spindelvorming in beide estrogeenreseptor-positiewe en estrogeenreseptor-negatiewe selle. Verder lei dit tot inhibisie van selgroei en induksie van apoptose in vinnig-verdelende selle in vitro en in vivo, ongeag van die sel se reseptorstatus. As gevolg hiervan word 2ME2 bestempel as 'n belowende antikankeragent. Nuwe navorsing het aan die lig gebring dat 2ME2 se meganisme van aksie beide die ekstrinsieke, asook die intrinsieke paaie van apoptose-induksie betrek, alhoewel die aksiemeganisme van $2 \mathrm{ME2} \mathrm{nog} \mathrm{steeds} \mathrm{nie} \mathrm{ontrafel} \mathrm{is}$ nie. In ons laboratorium is waargeneem dat die invloed van 2ME2 op normale selle nie so beduidend is soos in kankerselle nie. Dus blyk dit dat die werking van 2ME2 ook verskil ten opsigte van seltipe. Die doel van hierdie studie was om die invloed van 2ME2 op groei, morfologie, selsiklusprogressie en geenuitdrukking in 'n normale epiteelbors-sellyn (MCF-12A) te ondersoek en dit met kontroles wat die oplosmiddel vir 2ME2 bevat, te vergelyk. Tyds- $(24,39,48,72$ uur) en dosisafhanklike studies is uitgevoer en die invloed van 2ME2 is spektrofotometries met behulp van kristalviolet as DNS-kleuringsmiddel bepaal. Morfologiese veranderinge is met behulp van ligmikroskopie en fluoressensiemikroskopie waargeneem na hematoksilien en eosienkleuring, asook deur propidiumjodied en Hoechst 33342 as kleurstowwe te gebruik na 24 uur blootstelling aan 2ME2. Vloeisitometrie is gebruik om die invloed op selsiklusprogressie en apoptose-induksie te ondersoek. Dosisafhanklike studies het getoon dat $10^{-6} \mathrm{M} 2 \mathrm{ME} 2$ verantwoordelik was vir 50\% inhibisie van selgroei. Die invloed van $10^{-6} \mathrm{M} 2 \mathrm{ME} 2$ is gevolglik op selmorfologie geanaliseer na 24,48 en 72 uur van blootstelling. Hematoksilien en eosienkleuring het $60 \%$ abnormale selle (in metafase en apoptose) na 24 uur blootstelling getoon, insluitende morfologiese eienskappe kenmerkend van apoptose, naamlik sitoplasmiese krimping, membraanafstulping en apoptotiese liggaampies. Fluoressensiemikroskopie met propidiumjodied en Hoechst 33342 het die teenwoordigheid van abnormale mitotiese en apoptotiese selle bevestig. Vloeisitometriese analise met Annexin V het gedui op die teenwoordigheid van $1.9 \%$ selle in vroeë apoptose na 24 uur blootstelling aan $10^{-6} \mathrm{M} 2 \mathrm{ME} 2$ in vergelyking met die $1.7 \%$ selle in die kontrolemonster. Aligent se menslike 1A Oligo "Microarray" skyfies met 20,173 bekende menslike 60-mer oligonukleotiedpeilers sal in die toekoms gebruik word om die invloed van 2ME2 op geenuitdrukking in MCF-12A selle te

Suid-Afrikaanse Tydskrif vir Natuurwetenskap en Tegnologie, Jaargang 26 No. 1: Maart 2007 
bepaal. 'n Globale indruk van die invloed van bogenoemde middel op die geenuitdrukkingsprofiel van MCF-12 selle sal waardevolle inligting verskaf ten opsigte van molekulêre meganismes en seintransduksie geassosieer met 2ME2 in normale selle.

\title{
Aspekte van die ekologie van Bothriocephalus acheilognathi- besmetting in die Vaaldam
}

\author{
NR Retief $^{1}$, A Avenant-Oldewage ${ }^{1}$ \& HH du Preez ${ }^{2}$ \\ ${ }^{1}$ Departement Dierkunde, Universiteit van Johannesburg, Posbus 524, Aucklandpark, 2006, Suid- \\ Afrika \\ Department of Zoology, University of Johannesburg, P.O. Box 542, Auckland Park, 2006, South \\ Africa \\ ${ }^{2}$ Analitiese Dienste, Hidrobiologieseksie, Barrageweg, Posbus 3526, Vereeniging, Suid-Afrika, 1939 \\ Analytical Services, Hydro-biology Section, Barrage Road, P.O. Box 3526, Vereeniging, South \\ Africa, 1939 \\ ronaldoretief@hotmail.com; ao@na.rau.ac.za; hdupreez@randwater.co.za
}

\section{Aspects of the ecology of Bothriocephalus acheilognathi in the Vaal Dam}

Eighty Largemouth yellowfish were collected, their intestines opened and the position of attachment recorded. Parasite infection statistics were calculated and a $100 \%$ prevalence was recorded during all seasons with very high mean intensities (73.7-231.1). Bothriocephalus were located between $10 \%$ and $20 \%$ from the anterior end of the intestine.

Tydens 'n seisoenale studie in die Vaaldam is tagtig Grootbek-geelvisse versamel. Nadat die visse doodgemaak is, is die lengte en gewig bepaal. Nadoodse ondersoeke is uitgevoer, die intestinums is verwyder en die lengte daarvan bepaal. Die intestinum is in ' $n$ salienoplossing oopgesny. Die punt van vashegting van die eerste lintwurm, met betrekking tot die aanvang van die intestinum, is gemeet. Al die wurms is versigtig verwyder, getel en geïdentifiseer as Bothriocephalus acheilognathi Yamaguti, 1934. Die persentasie besmetting, gemiddelde besmettingsintensiteit en besmettingsmoontlikheid is saam met die seisoenlikse verskille bereken. Die verhouding van parasietintensiteit teenoor die intestinumlengte en totale lengte van elke vis is bereken. Die eerste lintwurm was tussen $10 \%$ en $20 \%$ vanaf die begin van die intestinum vasgeheg. Dit bevestig dat lintwurms hul vermoë om vette te metaboliseer, verloor het en dus naby die galblaas gevind word. Daar is 'n $100 \%$ besmetting tydens elke opname aangeteken. Die hoogste gemiddelde besmettingsintensiteit van 231.1 is tydens die herfsopname aangeteken terwyl die laagste gemiddelde besmettingsintensiteit van 73.7 tydens die someropname aangeteken is. Die gemiddelde besmettingsintensiteitswaarde aangeteken tydens die huidige studie is hoër as dié tydens 'n studie in 2000 by dieselfde lokaliteit. Die viskondisie is goed en die voortplantingsvermoë was nie benadeel deur die lintwurms nie. Toe die parasietintensiteite vergelyk is met die grootte van die visse, is geen korrelasie gevind nie. Dit dui aan dat vis van enige ouderdom met die parasiet besmet kan raak en dat die besmetting nie opbou oor tyd nie. Historiese data oor die Asiese lintwurmlewensiklus dui aan dat die lewensiklus binne een jaar voltooi word. 


\title{
Vergelykingsanalise tussen die gebruik van geochemiese en biomoniteringsdata vir besoedeling in Bloemspruit, Bloemfontein
}

\author{
N Scholtz ${ }^{1}$, R.G. Scholtz ${ }^{2}$ \& G. Stevens ${ }^{1}$ \\ ${ }^{1}$ Departement Geologie, Universiteit van die Vrystaat, Posbus 339, Bloemfontein, 9300 \\ Department of Geology, University of the Free State, P.O. Box 339, Bloemfontein, 9300 \\ ${ }^{2}$ Departement Entomologie, Nasionale Museum, Posbus 266, Bloemfontein, 9300 \\ Department of Entomology, National Museum, P.O. Box 266, Bloemfontein, 9300 \\ scholtzn.sci@mail.uovs.ac.za, entomol@nasmus.co.za
}

\section{Comparitive analysis between the use of geochemical and biomonitoring data for pollution in Bloem Spruit, Bloemfontein}

Stream sediment, water and biomonitoring analyses of Bloem Spruit, Bloemfontein, revealed that the city is a source for $\mathrm{NH}_{4}, \mathrm{NO}_{3}, \mathrm{PO}_{4}$ and $\mathrm{SO}_{4}$ in water as well as $\mathrm{Cr}, \mathrm{Fe}, \mathrm{Co}, \mathrm{Ni}$, Zn and $\mathrm{Cu}$ in stream sediment. ASPT scores increase downstream and show negative linear correlation with elements from stream sediment.

Die storting van huishoudelike en nywerheidsafval in opvang- en opgaargebiede lei tot potensiële probleme vir watergebruikers in Suid-Afrika. Die monitering van oppervlak-waterliggame rondom stede help nie net met die bestryding van besoedeling in oppervlakwater nie, maar bied ook goeie navorsingsgeleenthede om die bron van besoedeling te bestudeer en die uitwerking daarvan op akwatiese ekosisteme en uiteindelik ook die mens, beter te verstaan. Bloemspruit ontspring binne die stedelike gebiede van Bloemfontein en vloei in 'n oostelike rigting deur die stad, verby 'n landbougebied en sluit aan by die Renosterspruit wat stroomaf die Modderrivier binnevloei. In die huidige studie is daar by tien lokaliteite langs Bloemspruit water- en stroomsedimentmonsters geneem, asook 'n biomoniteringsanalise uitgevoer deur gebruik te maak van SASS 5. Laasgenoemde is 'n standaard protokol wat onwikkel is om die graad van besoedeling in Suid-Afrikaanse riviere te bepaal deur gebruik te maak van invertebraatpopulasies. Hierdie drie metodes is met mekaar vergelyk om die doeltreffendheid van elk te bepaal. Water is geanaliseer vir koper, lood, sink, fosfate, sulfate, nitrate en nitriet. Slegs een lokaliteit is vir Escherichia coli genaliseer en waardes hiervoor verkry was hoër as $2419 \mathrm{cfu} / 100 \mathrm{ml}$. E. coli waardes in die water is kommerwekkend aangesien verskeie siektes hierdeur veroorsaak kan word. Die elementkonsentrasies van die watermonsters was onbeduidend en laer as dié in die stroomsediment, behalwe vir 'n toename in fosfaatwaardes vanaf 'n punt waar dreineringswater vanaf huishoudelike gebiede by die spruit toegevoeg word. In teenstelling is daar stroomaf ' $n$ afname in koper-, lood- en sinkkonsentrasies in die stroomsedimentmonsters gevind, wat dui op 'n potensiële verdunning in elementkonsentrasies of die effek van 'n toename in afstand vanaf besoedelingsbron. Terwyl water- (chemiese) analises 'n akkurate aanduiding gee van die mate van elementkonsentrasies in water of stroomsediment op die spesifieke oomblik, gee biomonitering, alhoewel in minder detail, 'n beter beeld van die waterkwaliteit in die hede sowel as die verlede. Die rede hiervoor is dat waterorganismes wat die waterliggaam bewoon enige chemiese toestand in die water moet kan oorleef. SASS 5-tellings is bereken deur gebruik te maak van taksa met verskillende vlakke van toleransie teen besoedeling. Resultate toon 'n toename in ASPT- (average score per taxon) tellings stroomaf, aanduidend van 'n verbetering in waterkwaliteit weg vanaf die stad. 'n Vergelyking tussen ASPT-tellings en stroomsediment elementkonsentrasies, viz. Cr, Fe, Co, Ni, Zn en $\mathrm{Cu}$, gee 'n negatiewe liniêre verwantskap (ASPT-tellings neem toe stroomaf, terwyl elementkonsentrasies afneem). Hierdie elemente is toksies vir makroinvertebrata, vandaar die

Suid-Afrikaanse Tydskrif vir Natuurwetenskap en Tegnologie, Jaargang 26 No. 1: Maart 2007 
verhoogde ASPT-tellings met verlaging in elementkonsentrasies. ASPT-tellings toon egter goeie positiewe korrelasie met toename in $\mathrm{NH}_{4}, \mathrm{NO}_{3}, \mathrm{PO}_{4}$ en $\mathrm{SO}_{4}$ konsentrasies in die water, wat daarop dui dat hierdie elemente gunstige toestande skep vir makroinvertebrate. Die $\mathrm{NH}_{4}, \mathrm{NO}_{3}, \mathrm{PO}_{4}$ en $\mathrm{SO}_{4}$ is algemene bestanddele van kunsmis wat gebruik word in die landelike gebiede en gholfbane aan die oostekant van die stad waardeur Bloemspruit vloei. Die gevolgtrekking van hierdie studie is dat dié drie moniteringsmetodes, met die uitsondering van wateranalise, elk onafhanklik gebruik kan word om 'n soortgelyke eindresultaat te verkry, en dat die grootste bron van besoedeling van Bloemspruit binne die stedelike gebied van Bloemfontein geleë is.

\title{
Geïnduseerde uraan-fito-ekstraksie deur gebruik te maak van sitroensuur en hoë biomassa-gewasplante
}

\author{
OF Scholtz $^{1}$, N Scholtz ${ }^{2}$ \& GP Potgieter ${ }^{1}$ \\ ${ }^{1}$ Departement van Plantwetenskappe, Universiteit van die Vrystaat, Posbus 339, Bloemfontein, \\ 9300 \\ Department of Plant Sciences, University of the Free State, P.O. Box 339, Bloemfontein, 9300 \\ ${ }^{2}$ Departement Geologie, Universiteit van die Vrystaat, Posbus 339, Bloemfontein, 9300 \\ Department of Geology, University of the Free State, P.O. Box 339, Bloemfontein, 9300 \\ scholtzo.sci@mail.uovs.ac.za
}

\section{Citric acid induced phytoextraction of uranium using high biomass crop plants}

The efficiency of citric acid to induce $U$ accumulation and translocation in crop species was evaluated. A more than 85-fold increase was observed in shoots of Indian mustard (Brassica juncea (L. Czern. cv. 211000) following citric acid additions to the soil. This technology may provide a remediation alternative for $U$ contaminated soils.

Uraan (U) -kontaminasie van bogrond ontwikkel onder meer as gevolg van die produksie en prosessering van U vir die kernindustrie. Konvensionele rehabiliteringsmetodes sluit in die opgrawe, vervoer en stoor van grond as radioaktiewe afval, maar hierdie prosesse is duur en verg addisionele grondremediëring. Fito-ekstraksie van uraan stel 'n koste-effektiewe strategie vir die remediasie van U in gekontamineerde bogrond voor. Fito-ekstraksie word gedefinieer as die opname van swaarmetale deur plantwortels en die vervoer deur die vaskulêre sisteem tot in die bogrondse plantdele (translokering). Die bogrondse dele word vervolgens geoes en die metaal word verwyder uit die sisteem. 'n Sleutel tot die sukses van fito-ekstraksie is die verhoging van die biobeskikbaarheid van die metale in die grond. Geïnduseerde fito-ekstraksie behels die byvoeging van sekere organiese of sintetiese amendemente (kelate) by die grond om die swaarmetale in die grond meer wateroplosbaar (biobeskikbaar) te maak vir wortelopname. Hierdie kelate bind die swaarmetaal in 'n oplosbare metaalkelaatkompleks en funksioneer ook in die translokering van die metaal tot in die bogrondse plantdele. Die potensiaal van sekere gewasspesies om U te fito-ekstraeer vanaf lae vlakke van U-kontaminasie (28 mg kg-1) in grond, met behulp van 'n sitroensuur (0-25 mmol kg-1 grond), is in die kweekhuis getoets. Twee variante van Indiese mosterd (Brassica juncea (L.) Czern. 211000 en 426308) en sonneblom (Helianthus annuиs L.) is gebruik as toetsplante. Sitroensuur het die biobeskikbare U in die grond merkwaardig verhoog, vanaf $0.7 \mathrm{mg} \mathrm{kg}^{-1}$ ( 0 mmol sitroensuur kg-1 grond) tot $19 \mathrm{mg} \mathrm{kg}^{-1}$ (25 mmol kg${ }^{-1}$ sitroensuur $\mathrm{kg}^{-1}$ grond). Dit het vervolgens die $\mathrm{U}$ in bogrondse plantdele ook verhoog; bogrondse $B$. juncea 211000 het byvoorbeeld verhoog vanaf $21 \mathrm{mg} \mathrm{kg}^{-1}$ in kontroleplante $(0 \mathrm{mmol}$ 
sitroensuur kg ${ }^{-1}$ grond) tot $510 \mathrm{mg} \mathrm{kg}^{-1}$ met sitroensuurbyvoeging ( $25 \mathrm{mmol} \mathrm{kg}^{-1}$ sitroensuur kg-1 grond). Die mate van bogrondse U-opname is ook getoets met ' $\mathrm{n}$ sitroensuurbyvoeging van 12.5 mmol kg-1 gevolg deur dieselfde toediening drie dae later. Hierdie byvoeging het die U-opname in $B$. juncea 211000 verhoog tot $1788 \mathrm{mg} \mathrm{kg}^{-1}$. Hierdie resultate stel 'n moontlike omgewingsvriendelike rehabilitering van U-gekontamineerde grond voor.

\title{
Termitaria van Trinervitermes trinervoides (Isoptera: Termitidae) as hulpmiddel vir uraaneksplorasie in Suid-Afrika
}

\author{
N Scholtz ${ }^{1}$, RG Scholtz ${ }^{2} \&$ S Kara ${ }^{1}$ \\ ${ }^{1}$ Departement Geologie, Universiteit van die Vrystaat, Posbus 339, Bloemfontein, 9300 \\ Department of Geology, University of the Free State, P.O. Box 339, Bloemfontein, 9300 \\ ${ }^{2}$ Departement Entomologie, Nasionale Museum, Posbus 266, Bloemfontein, 9300 \\ Department of Entomology, National Museum, P.O. Box 266, Bloemfontein, 9300 \\ scholtzn.sci@mail.uovs.ac.za; entomol@nasmus.co.za
}

\section{Termitaria of Trinervitermes trinervoides (Isoptera: Termitidae) as aid in uranium exploration, South Africa}

The use of termitaria of Trinervitermes trinervoides (Isoptera: Termitidae) in geochemical exploration for uranium in the Edenburg district, South Africa was investigated. The U-Mo ore association can be identified using $U, M o$ and $W$ obtained from termitaria samples. Termites show a positive receptiveness for uranium containing soils that should receive further investigation.

Die gebruik van termiete, spesifiek Trinervitermes trinervoides (Isoptera: Termitidae) in die geochemiese eksplorasie vir uraan op die plaas Mooifontein 76 in die Edenburg-distrik, KarooUraanprovinsie is bestudeer. Die gebruik van termiete as indikatorspesies vir ondergrondse mineralisasie toon doeltreffende resultate op verskeie gemineraliseerde gebiede. Besonderse hoë vlakke $\mathrm{Au}, \mathrm{Pb}, \mathrm{Zn}, \mathrm{Mo}$ en $\mathrm{Ag}$ is gedokumenteer in termitaria in Zimbabwe terwyl die Jwaneng Kimberlietpyp in Botswana ontdek is met termitaria-eksplorasie. Uraan is ' $n$ radioaktiewe element en is gevaarlik vir lewende organismes indien die metaal of geassosieerde afbouprodukte ingeneem word. Alhoewel die huidige studie gebaseer is op die gebruik van termitaria in eksplorasie, is die potensiële effek van uraan en geassosieerde radiasie op die termiete ook bestudeer. Terwyl daar 'n reeks gepubliseerde materiaal bestaan waarin bewys word dat hoë vlakke van radiasie gevaarlik is vir biologiese materiaal, is daar ook gedokumenteerde studies wat bewys dat biologiese materiaal gestimuleer word deur lae vlakke van radiasie. Hierdie studie het dus ook 'n ondersoek ingesluit om te bepaal of termiete enige voor- of afkeur toon vir grond wat verskillende konsentrasies uraan en geassosieerde elemente bevat. Korrelasie (r) tussen die konsentrasies van $U$ en ander elemente vanuit termitaria verkry deur ICP-MS analise, was swak (-0.04 d" rd" 0.55) met die beste korrelasie tussen $\mathrm{U}$ en $\mathrm{S}(\mathrm{r}=0.55)$ wat daarop dui dat die gemineraliseerde sone moontlik verryk is in organiese materiaal. Die bron vir S kan swawel-reduserende bakterieë wees wat aktief is in reduserende omgewings. Aangesien U afgeset word in sulke omgewings, kan dit moontlik wees dat afsetting van die metaal plaasgevind het in areas waar hierdie bakterieë aktief was. Soortgelyke korrelasies is uitgevoer met Mo. Hierdie korrelasies was meestal swak negatief (-0.57 d" rd" 0.89) behalwe vir 'n goeie korrelasie tussen $\mathrm{W}$ en $\mathrm{Mo}(\mathrm{r}=0.89)$. Die Mo/W assosiasie kom voor by kontak-metasomatiese 
afsettings en die verhoogde W waardes kan daarop dui dat intrusiewe liggame 'n rol gespeel het in U/ Mo afsetting in die area. Gemiddelde elementkonsentrasies is verkry vanuit termitaria wat die ertsliggaam oorlê $(n=68)$ en is vergelyk met termitaria weg vanaf die ertsliggaam $(n=8)$ sowel as met termitaria geleë na die suide $(n=11)$ waar 'n moontlike ekstensie van die ertsliggaam bestaan. U, Mo en $\mathrm{W}$ is die enigste elemente wat verhoogde konsentrasies bo-op die ertsligaam toon in vergelyking met waardes weg vanaf die ertsligaam. Die U-Mo-W-assosiasie toon ook 'n verhoging na die suide en dus 'n moontlike ekstensie van die ertsliggaam. 'n Ondersoek na die moontlike voor- of afkeur van Trinervitermes trinervoides vir $\mathrm{U}$ het getoon dat die spesie 'n voorkeur toon vir grond wat ' $\mathrm{n}$ gemiddelde konsentrasies U bevat (8.8dpm) en 'n afkeur het vir hoë U-konsentrasies in grond (628dpm). Daar is ook 'n verhoogde getal termitaria bokant die ertsligaam op Mooifontein 76 gevind, wat moontlik daarop dui dat die spesie 'n voorkeur het vir U-bevattende grond.

\title{
Biospeleologiese bestudering in 'n karstsisteem gevorm in vroeë proterosoise-gesteentes, Suid-Afrika
}

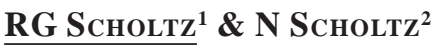 \\ ${ }^{1}$ Departement Entomologie, Nasionale Museum, Posbus 266, Bloemfontein, 9300 \\ Department of Entomology, National Museum, P.O. Box 266, Bloemfontein, 9300 \\ ${ }^{2}$ Departement Geologie, Universiteit van die Vrystaat, Posbus 339, Bloemfontein, 9300 \\ Department of Geology, University of the Free State, P.O. Box 339, Bloemfontein, 9300 \\ entomol@nasmus.co.za; scholtzn.sci@mail.uovs.ac.za,
}

\section{Biospeleological investigation of a karst system formed in early proterozoic rocks, South Africa}

The first biospeleological study of its kind to be completed in Crystal Cave collected invertebrates from 11 orders, 15 families and 20 genera using handcollecting methods, as well as preservative pitfall traps. Spider beetles from the family Ptinidae (Coleoptera) dominated numbers, followed by the cribbelate spider Vidole sothoana Griswold (Arachnida, Phyxelididae)

Ontleding en beskrywing van lewende organismes en hul habitats skep 'n groter bewaringspotensiaal. Alhoewel spesie-opnames, sowel as beskrywinge van sommige ekologiese sisteme van 'n paar grotte in suidelike Afrika al gepubliseer is, is hierdie die eerste gedokumenteerde biospeleologiese studie op die Crystal Cave grotsisteem in die Noordwes-provinsie, Suid-Afrika. Aangesien invertebrate ' $n$ baie belangrike rol speel in ekologiese prosesse, en een van die grootste komponente van globale biodiversiteit is, is hierdie groep van grootskaalse bewaringsbelang. Die bestudering van invertebrate binne ongedokumenteerde lokaliteite in Suid-Afrika is dus noodsaaklik aangesien troglobiete (verpligte grotbewoners) en "cavernicoles" (opsionele grotbewoners) 'n baie hoë graad van gelokaliseerde endemisme toon. Crystal Cave is geleë binne dolomitiese gesteentes wat behoort tot die Malmani Subgroep van die Transvaal Supergroep. Hierdie grot is een van ' $n$ reeks grotte in die area en het gevorm deur karstoplossing en vergroting deur instorting. Aangesien karstoplossing ' $\mathrm{n}$ produk is van ondergrondse waterbeweging, en kalsiumkarbonaatafsetting in 'n grot begin met waterdreinering, kan die ouderdom van grotte gemeet word deur radiometriese bepalings in stalaktiete en stalagmiete. Alhoewel hierdie studies ongedokumenteer is, of nooit plaasgevind het binne Crystal Cave nie, is 'n studie in die laat sestigerjare uitgevoer op die verwantskap tussen grotontwikkeling en erosievlakke in die Transvaal 
Supergroep. Hierdie studie het gevind dat grotontwikkeling in hierdie Supergroep tydens die Afrika en Post Afrika 1-siklusse van erosie plaasgevind het. Die ouderdom van die grotte in die Potchefstroom-Carletonville omgewing word dus as einde Kryt tot vroeg Tersiêr, wat min of meer 'n aanduiding kan wees van die tydperk van isolasie van die troglobiete, beskryf . Die bestudering van invertebrate binne Crystal Cave het twee besoeke behels. In die eerste besoek is daar verskeie putvalle binne die grot uitgeplaas, en invertebrate is ook per hand versamel. Met 'n volgende besoek, drie maande later, is die putvalle opgetel en meer sorgvuldig met die hand versamel. Verskeie makro-invertebraatspesies is in die grot versamel. Die spinnekopkewer (Insecta, Coleoptera, Ptinidae) het die meeste individue opgelewer, gevolg deur die spinnekop Vidole sothoana Griswold (Arachnida, Phyxelididae). In grotte, waar geen outogtone energie gegenereer word deur fotooutotrowe nie, moet organismes hulself wend na energiebronne wat die grot binnekom deur middel van water, gravitasie, diere se ekskreta of verottende karkaste. Aangesien hierdie grot droog is, is die hoofbron van voedsel die dik lae vlermuisguano wat 'n groot deel van die vloer van die grot bedek. Invertebrate van 11 ordes, 15 families en 20 genera is versamel in Crystal Cave, waar die grootste diversiteit in die Coleoptera voorgekom het. Geen van die invertebrate wat in die grot versamel is, kan as werklik troglobieties beskryf word nie, aangesien hul voorheen in ander soortgelyke habitatte buite grotte versamel is.

\title{
Ekologiese parameters van Lamproglena hoi- (Copepoda: Lernaeidae) infeksie op die Bosveld kleinskub-geelvis, Labeobarbus polylepis (Boulenger 1907)
}

\author{
$\underline{\text { A Austin }}^{1}$ \& A Avenant-Oldewage ${ }^{1}$ \\ ${ }^{1}$ Departement Dierkunde, Universiteit van Johannesburg, Posbus 524, Aucklandpark, 2006, \\ Suid-Afrika \\ Department of Zoology, University of Johannesburg, P.O. Box 524, Auckland Park, 2006, South \\ Africa. \\ s200107629@yahoo.com; ao@na.rau.ac.za
}

Ecological parameters of Lamproglena hoi (Copepoda: Lernaeidae) infection on the Bushveld smallscale yellowfish, Labeobarbus polylepis (Boulenger 1907)

Lamproglena hoi was collected from Labeobarbus polylepis in the Pongola and Assegai Rivers. This study describes the high infections during winter, consisting of ovigerous females that are able to produce larvae in early spring.

Die genus Lamproglena is in 1832 deur Von Nordmann beskryf. Buiten Lamproglena lichiae is die volwasse wyfies van al die spesies in die genus kieuparasiete van varswatervisse. Vyf van die 37 spesies is afkomstig van suidelike Afrika. Lamproglena hoi (Dippenaar et al. 2001) is die mees onlangsbeskryfde spesie. Dit is versamel in die Spekboomrivier in Mpumalanga op Labeobarbus marequensis en Labeobarbus polylepis. Geen ekologiese data is beskikbaar oor hierdie parasiet nie. Die studie beoog om die infeksie deur die parasiet beter te verstaan. Bosveld kleinskubgeelvis, Labeobarbus polylepis is versamel gedurende Junie 2006 in die Pongola- en Assegaairiviere, Mpumalanga, Suid-Afrika en die kieue is ondersoek vir die teenwoordigheid van parasiete. Lamproglena hoi is versamel vanaf die kieufilamente. Die parasiete is in 'n uitgestrekte posisie met warm asetoformaldehiedalkohol gefikseer en daarna gepreserveer in $70 \%$ etanol. Die

Suid-Afrikaanse Tydskrif vir Natuurwetenskap en Tegnologie, Jaargang 26 No. 1: Maart 2007 
identifikasie van die parasiet het plaasgevind in die laboratoriums van die Universiteit van Johannesburg. Vyf-en-twintig L. hoi individue (persentasie besmetting $20.69 \%$, gemiddelde besmettingsintensiteit $=4.17$, besmettingsmoontlikheid $=0.86$ ) is versamel vanaf 29 visse in die Pongolarivier. Ses-en-veertig L. hoi-individue (persentasie besmetting $40.00 \%$, gemiddelde besmettingsintensiteit $=3.83$, besmettingsmoontlikheid $=1.53$ ) is versamel vanaf 30 visse in die Assegaairivier. Die wyfies het almal volledig ontwikkelde ovaria gehad en eiersakkies met bevrugte eiers gedra. Die studie beskryf nuwe lokaliteite en die buitengewone hoë persentasie besmetting, gemiddelde besmettingsintensiteit en besmettingsmoontlikheid van die parasiet gedurende die winteropname. Dit is ook aangetoon dat die parasiete in die winter reeds eiers produseer wat waarskynlik in die vroeë lente gashere sal besmet.

\section{Verwantskap tussen allantoïnaseaktiwiteit en ureïedinhoud in sojaboonblare}

\section{DJ Mellet, PDR van Heerden \& GHJ Krüger}

Skool vir Omgewingswetenskappe en Ontwikkeling, Afdeling Plantkunde, Noordwes-Universiteit, Potchefstroom, 2520

School of Environmental Sciences and Development, Plant Studies, North-West University, Potchefstroom, 2520

plbdjm@puk.ac.za; plbpdrvh@puk.ac.za; plbghjk@puk.ac.za

\section{Relationship between allantoinase activity and ureide content in soybean leaves}

During nitrogen fixation, ureide is produced, but before it can be utilized it has to be converted to urea by allantoinase. These experiments were done to determine the allantoinase activity and the ureide content over 24 hours. Young growing as well as young expanded leaves were sampled and, the ureide content and allantoinase activity were determined. Similar changes occurred in both of the leaf ages, and there is a clear inverse relationship between allantoinase activity and ureide content in soybean leaves.

Tydens simbiotiese stikstoffiksering deur Bradyrhizobium japonicum in die wortelknoppies van sojabone word allantoïen en allantoïensuur gevorm wat gesamentlik bekend staan as ureïede. Ureïede is 'n stabiele uitvoerproduk van bakteriële nitrogenase-aktiwiteit en word na sintese deur die xileem vanuit die wortelknoppies na die bogrondse plantorgane vervoer vir gebruik tydens algemene stikstofmetabolisme. Voordat ureïede benut kan word, moet dit eers omgeskakel word na ureum deur 'n kataboliese weg wat onder andere die werking van die ensiem allantoïenase behels. Alhoewel allantoïenase skynbaar 'n sleutelrol vervul tydens die proses van ureïedkatabolisme in sojaboonblare, is baie min bekend oor die eienskappe en regulering van hierdie ensiem. Die hoofrede vir die gebrek aan kennis kan toegeskryf word aan tegniese probleme rakende die akkurate bepaling van allantoinase-aktiwiteit in die verlede. Onlangs is ' $n$ sensitiewe metode egter ontwikkel vir die bepaling van allantoinase-aktiwiteit in selekstrakte. Optimalisering van hierdie metode, vir gebruik in kru-ekstrakte van sojaboonblare, is onlangs deur ons laboratorium uitgevoer en aangewend om allantoïenase-aktiwiteit in sojaboonblare te bestudeer. In hierdie studie rapporteer ons nuwe bevindinge rakende allantoïenase-aktiwiteit oor 'n daaglikse siklus en die verwantskap wat bestaan tussen allantoïenase-aktiwiteit en ureïedinhoud van blare. Hierdie inligting is noodsaaklik vir verdere navorsing aangaande stremmingsfaktore, soos droogte en lae temperatuur, se effek op

Suid-Afrikaanse Tydskrif vir Natuurwetenskap en Tegnologie, Jaargang 26 No. 1: Maart 2007 
ureïedkatabolisme en die rol wat dit speel in die inhibering van simbiotiese stikstoffiksering in wortelknoppies. Dit word dikwels gespekuleer dat versteurde ureïedkatabolisme tydens omgewingstremming aanleiding gee tot terugvoerinhibisie van nitrogenase-aktiwiteit, maar geen konsekwente bewyse ten gunste van hierdie hipotese kon nog verskaf word nie. Die akkurate kwantifisering van allantoinase-aktiwiteit maak dit egter moontlik om meer gedetailleerde navorsing oor hierdie onderwerp te doen. Die hoofdoel van hierdie ondersoek was om vas te stel hoe allantoïenase-aktiwiteit deur die verloop van 'n dag-/nagsiklus verander en of daar enige verwantskap bestaan tussen ureïedinhoud en allantoïenase-aktiwiteit in sojaboonblare. Sade van die sojaboongenotipe PAN809 is in potte met vermikuliet gesaai in die teenwoordigheid van Bradyrhizobium japonicum entstof, waarna saailinge in 'n temperatuurbeheerde groeikamer gekweek is vir 'n periode van vier weke. 'n Jong groeiende blaar (terminale pinna ongeveer $25 \mathrm{~mm}$ lank) asook die jongste volwasse blaar van drie afsonderlike plante, is vervolgens elke twee uur deur die verloop van 'n 24 uur dag-/nagsiklus geoes en in vloeibare stikstof gevries vir die bepaling van allantoïenase-aktiwiteit en ureïedinhoud. Daar is bevind dat allantoïenase groot veranderinge in aktiwiteit ondergaan het gedurende die verloop van 'n dag-/nagsiklus. Gedurende die nag was allantoïenase-aktiwiteit baie laer as gedurende die eerste vier uur van die daaropvolgende ligperiode. Gedurende die res van die ligperiode het allantoïenase-aktiwiteit weer na 'n vlak verander soortgelyk as gedurende die nag. Die drastiese veranderinge in allantoïenase-aktiwiteit dui op aansienlike regulering van die ensiem deur meganismes wat tans nog onbekend is. 'n Verdere bevinding was dat 'n omgekeerde verwantskap bestaan het tussen allantoïenase-aktiwiteit en ureïedinhoud. Gedurende die nag, wanneer allantoïenase-aktiwiteit die laagste was, was die ureïedinhoud van dieselfde blare die hoogste. Die drastiese toename in allantoïenase-aktiwiteit gedurende die eerste vier uur van die ligperiode het saamgeval met 'n groot afname in ureïedinhoud. Gedurende die res van die ligperiode, toe allantoïenase-aktiwiteit weer verlaag het, het die ureïedinhoud van blare stelselmatig verhoog tot maksimum vlakke soos gemeet in die donker. Hierdie resultate dui aan dat 'n verhoging in allantoïenase-aktiwiteit lei tot verhoogde ureïedkatabolisme, soos gereflekteer deur die verlaging in ureïedinhoud. Beide groeiende en volwasse blare het soortgelyk gereageer, wat dus 'n algemene respons op die vlak van die heelplant aandui. Indien omgewingstremming allantoinase-aktiwiteit in blare sou inhibeer, dan sal dit heel moontlik versteurings in normale ureiedvlakke in bogrondse plantorgane veroorsaak, met moontlike ernstige implikasies vir volgehoue simbiotiese stikstoffiksering in die wortelknoppies. 


\title{
Invloed van Sutherlandia frutescens-ekstrakte op selgetalle, morfologie en geenuitdrukkingsprofiele in 'n menslike borsadenokarsinoomsellyn
}

\author{
BA Stander ${ }^{1}$, TJ Steynberg ${ }^{1}$, S Marais ${ }^{1}$, D Theron ${ }^{2}$, F Joubert $^{3}$, C Albrecht $^{4}$ \& AM \\ JOUBERT ${ }^{1}$ \\ ${ }^{1}$ Departement Fisiologie, Universiteit van Pretoria, Posbus 2034, Pretoria, 0001, Suid-Afrika \\ Department of Physiology, University of Pretoria, P.O. Box 2034, Pretoria, 0001, South Africa \\ ${ }^{2}$ ACGT Microarray-fasiliteit, Universiteit van Pretoria, Pretoria, 0001, Suid-Afrika \\ ACGT Microarray Facility, University of Pretoria, Pretoria 0001, South Africa \\ ${ }^{3}$ Bio-informatika en gerekenariseerde Biologie-eenheid, Universiteit van Pretoria, Pretoria, Suid- \\ Afrika \\ Bioinformatics and Computational Biology Unit, University of Pretoria, Pretoria 0001, South \\ Africa \\ ${ }^{4}$ KANSA, Bedfordview, 2008, Suid-Afrika/South Africa \\ ${ }^{1}$ s25432614@tuks.co.za; ${ }^{1}$ TSteynberg@csir.co.za; ${ }^{1}$ sumari.maas@up.ac.za; \\ ${ }^{2}$ danie.theron@fabi.up.ac.za; ${ }^{3}$ fourie.joubert@up.ac.za; ${ }^{4}$ calbrec@iafrica.com; \\ 1annie.joubert@up.ac.za
}

\section{Influence of Sutherlandia frutescens extracts on cell numbers, morphology and gene expression profiles in a human breast adenocarcinoma cell line}

S. frutescens extracts $(1.5 \mathrm{mg} / \mathrm{ml})$ decreased malignant cell numbers to $50 \%$. Light and fluorescence microscopy revealed apoptotic morphology. Pilot microarray studies contributed to the unraveling of signal transduction linked with $\underline{\text { S. frutescens }}$ extracts.

Sutherlandia frutescens is 'n bekende Suid-Afrikaanse medisinale plant wat tradisioneel gebruik word vir kankers, diabetes, verskeie inflammasies en meer onlangs vir die algehele verbetering van gesondheid in kanker- en HIV/VIGS pasiënte. Die invloed van kru S. frutescens ekstrakte (voorberei met $70 \%$ etanol) is op selgetalle, morfologie en geenuitdrukkingsprofiele in MCF-7 menslike borsadenokarsinoomselle geëvalueer. Tyds- (24, 38, 48 en 72 uur) en dosisafhanklike (0.5-2.5mg/ $\mathrm{ml}$ ) studies is uitgevoer en selgroei is spektrofotometries met behulp van 'n DNS-kleurstof bepaal. Die invloed van kru S. frutescens ekstrakte op morfologie is met behulp van ligmikroskopie en fluoressensiemikroskopie bepaal na hematoksilien-eosienkleuring, asook propidiumjodied en Hoechst 33258 as kleurstowwe te gebruik na 24 blootstelling met $S$. frutescens in vergelyking met kontrole-behandelde selle. Agilent se menslike 1A Oligo Microarray-skyfies met 20,173 bekende menslike 60-mer oligonukleotied-peilers is gebruik om genomiese inligting te verkry om die meganisme van $S$. frutescens-ekstrakte in MCF-7 te ontleed. Spektrofotometriese analise van DNSinhoud het getoon dat die getal kwaadaardige selle statisties betekenisvol tot $50 \%$ afgeneem het na 24 uur blootstelling aan $1.5 \mathrm{mg} / \mathrm{ml}$ S. frutescens-ekstrakte in vergelyking met kontrole-behandelde selle. Lig-, fluoressensie- en skandeer-elektronmikroskopie het eienskappe van apoptose, insluitend sitoplasmiese krimping, membraanafstulping en apoptotiese liggaampies aangetoon na 24 uur blootstelling aan kru S. frutescens ekstrakte in vergelyking met kontrole-behandelde selle. "Microarray" analise het getoon dat 'n totaal van 345 gene differensieel statisties betekenisvol $(P<0.01$, log-odds waarde $>1.2)$ uitgedruk is. Gene wat differensieel uitgedruk is, en ' $n$ rol in apoptose, selsiklusprogressie en seintransduksie speel, is geïdentifiseer as: tumornekrose faktor reseptor superfamilie 10a en b (DR4, DR5), CARMA1, Proteïeninhibitor van geaktiveerde STAT1 (PIAS1),

Suid-Afrikaanse Tydskrif vir Natuurwetenskap en Tegnologie, Jaargang 26 No. 1: Maart 2007 
$V$-myc miëlositomatose virale onkogeen homoloog 2, NFKB inhibitor interaktiewe Ras-tipe 2, AKT1 substraat 1 en Neutrale sphingomiëlinase-2. Die voorlopige geenuitdrukkingsprofiele verskaf waardevolle inligting ten opsigte van molekulêre meganismes en seintransduksie geassosieer met $70 \%$ etanoliese $S$. frutescens ekstrakte in 'n kankersellyn.

\section{Organiese sure onder die soeklig as voedselpreserveermiddels}

\section{THERON, \& JFR LuES}

UAFSB, Skool vir Landbou en Omgewingswetenskappe, Sentrale Universiteit vir Tegnologie, Bloemfontein, 9300

UAFSB, School of Agricultural and Environmental Sciences, Central University of Technology, Bloemfontein, 9300

mtheron@cut.ac.za; rlues@cut.ac.za

\section{Organic acids revisited as food preservatives}

Organic acids have for many years been valuable food preservatives, but their effectiveness is being questioned because of extensive use. Antimicrobial profiles of 15 organic acids were compiled against food-associated pathogenic bacteria and susceptibility was found to be decreasing. Bacteria seem to have various mechanisms to overcome inhibition by organic acids.

Ondanks die gebruik van verskeie preserveermiddels en -metodes, word wêreldwyd steeds baie probleme ondervind as gevolg van voedselbederf en -vergiftiging. Tot ongeveer 'n dekade gelede was die preserveringsproses op sigself van min belang vir die publiek. Vandag is daar' $n$ toenemende aanvraag vir die produksie van voedsel met minder preservering (metodes of byvoeg van middels). Belangstelling in biopreservering van voedselsisteme het die ontwikkeling van nuwe, meer natuurlike antimikrobiese middels noodsaaklik gemaak en in respons op die tendens van die moderne verbruiker, asook voedselwetgewing, word die voedselindustrie met groot uitdagings gekonfronteer. Daar bestaan ook die moontlikheid dat organiese voedsel 'n hoër risiko loop om gekontamineer te word. Organiese sure is reeds vir baie jare waardevolle voedselpreserveermiddels. Tog is min data beskikbaar oor hulle effektiwiteit in die handelswêreld en die gebruik van organiese sure word ook nie wyd aanvaar nie, veral in dekontaminasie van vleis. Die aanwendbaarheid van organiese sure word bevraagteken en heelwat navorsing is nodig om hulle bruikbaarheid vas te stel. Die vermoede het ontstaan dat oormatige gebruik van organiese sure lei tot ontwikkeling van weerstandigheid sowel as suurtoleransie by mikroörganismes wat voedselpatogene in staat stel om te oorleef in die lae $\mathrm{pH}$ van die gastriese maag van die mens. Dit is ook verontrustend dat die mesofiliese enterobakterieë ressorteer onder die patogene mees weerstandig teen organiese sure. Weens die menige voordele in die gebruik van organiese sure, is dit essensieel dat hulle onder 'n soeklig geplaas word, om te verhoed dat hulle onbruikbaar raak as preserveermiddels. Hierdie studie is gedoen om die gevoeligheid van voedsel-geassosieerde bakterieë vir organiese sure te bepaal, asook die meganismes waarmee die organismes weerstandigheid ontwikkel. Antimikrobemiddel gevoeligheidsprofiele teen 15 organiese sure is saamgestel vir standaard stamme van voedselpatogene, deur hulle minimum inhibitoriese konsentrasies (MIK's) te bepaal met die agarverdunningsmetode. Dit is bekend dat organiese sure optimum inhibitoriese aktiwiteit vertoon by ' $\mathrm{n}$ lae $\mathrm{pH}$, so hierdie toets is herhaal by $\mathrm{pH}$ 5. Induksie van weerstandigheid in gevoelige isolate is uitgevoer deur blootstelling aan toenemende konsentrasies organiese suur. Buitemembraanproteïensamestelling van alle isolate is bepaal met behulp van SDS-PAGE en resultate, gevind met 
gevoelige isolate, vergelyk met die van weerstandiges. MIK-waardes van die standaard stamme was merkbaar hoog, veral vir sorbiese (hoogste), kapriese, bensoiëse en laktiese sure, vergeleke met konsentrasies gebruik in die literatuur en handelsprotokolle. Die mees weerstandige organismes was Pseudomonas aeruginosa en Klebsiella pneumoniae. By pH 5 was die MIK's baie laer as by neutrale $\mathrm{pH}$. Al die isolate was egter nie so in staat om te groei by hierdie lae $\mathrm{pH}$ nie. Die vraag ontstaan dus of dit werklik die organiese sure is wat meer aktief is en of die laer $\mathrm{pH}$ nie moontlik net die gevoeligheid van die organismes verhoog nie? Daar is verskeie faktore wat in aanmerking geneem moet word wanneer die effektiwiteit van 'n preserveermiddel bepaal word (groeistadium, $\mathrm{pH}$, voedseltipe, temperatuur, ensovoorts), maar as die MIK's vir standaard stamme, wat nog nie eers blootgestel is aan voedselpreserveermiddels nie, redelik hoog is, mag dit verontrustend wees om uit te vind wat die werklike situasie is ten opsigte van organismes geïsoleer vanuit geprosesseerde voedsel. Alhoewel dit nie die enigste faktor is nie, blyk die buitemembraanproteïenstruktuur van bakterieë ' $n$ belangrike rol te speel in die ontwikkeling van bestandheid teen organiese sure. Hierdie studie is egter nog in die beginstadium en verskeie ander meganismes, oordraagbaarheid en geenproduksie word tans ondersoek.

\section{Verwantskap tussen voedingsukses en groepgroottes van vee- reiers (Bubulcus ibis) in die sentrale Vrystaat}

\section{HJB BUtLER \& OB KoK}

Departement Dierkunde en Entomologie, Universiteit van die Vrystaat, Posbus 339, Bloemfontein, 9300

Department of Zoology and Entomology, University of the Free State, P.O. Box 339, Bloemfontein, 9300

butlerhj.sci@mail.uovs.ac.za; kokob.sci@mail.uovs.ac.za

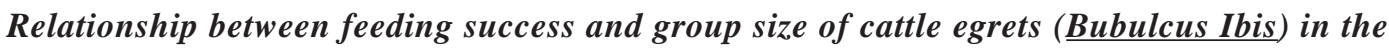 central Free State}

Cattle egrets form bigger groups when the birds feed independently of hosts compared to birds observed in association with hosts. Results of a feeding experiment as well as the occurrence of feeding lines suggest that cattle egrets achieve a higher success when feeding in a group.

Die sentrale hoëveld verteenwoordig een van die vernaamste verspreidingsgebiede van vee-reiers (Bubulcus ibis) in Suid-Afrika. Die voëlsoort kom dan ook as algemene, broeiende standvoël oor die hele Vrystaat voor. Min inligting is egter oor die voedingsgewoontes van vee-reiers in oop, kort grasveld bekend. Gereelde veldopnames van vee-reiers en geassosieerde gashere is oor 'n aaneenlopende tydperk van vyf en 'n half jaar (Oktober 1995-April 2001) in die sentrale gedeelte van die Vrystaat, wat deur die dorpe Bloemfontein, Dealesville, Dewetsdorp, Senekal en Ventersburg begrens word, onderneem. Ten einde eksperimenteel te bepaal of die voedingsukses van vee-reiers deur groepgrootte beïnvloed word, is voedingseksperimente met verskillende groepgroottes en bekende prooidigthede in beide kort en lang gras gedoen. Klaarblyklik bestaan daar 'n noue verband tussen die voedingsukses van vee-reiers en die grootte van die groep waarin daar gevoed word. Ongeag habitat of tydstip van die dag kom vee-reiers wat onafhanklik van gashere voed oor die algemeen in groter groepe voor as dié wat in noue assosiasie met hoefdiere voed. Resultate van voedingseksperimente, asook die uitsonderlike voorkoms van sogenaamde voedingslinies, bevestig 
die verskynsel dat vee-reiers in groepsverband sonder uitsondering hoër voedingsuksesse as enkelinge behaal. Hierteenoor is die gemiddelde groepgrootte van vee-reiers wat in assosiasie met gashere voed nie alleen kleiner nie, maar ook merkwaardig konstant met betrekking tot spesifieke situasies. As gevolg van die habitat en weispoed van die betrokke gashere het vee-reiers die hoogste voedingsukses (aantal prooi-items) met die minste energie-insette (aantal treë) in assosiasie met beeste, en in 'n mindere mate die naverwante buffel, behaal.

\section{'n Ondersoek na die bio-akkumulering van dioksienagtige stowwe in geselekteerde riviere in die Vaaldriehoekstreek, Gauteng, Suid-Afrika}

\section{Nieuwoudt, R Pieters \& H Bouwman}

Skool vir Omgewingswetenskappe en Ontwikkeling. Noordwes-Universiteit, Potchefstroom, 2520 School of Environmental Sciences and Development, North-West University, Potchefstroom, 2520

Claudine.Nieuwoudt@nwu.ac.za; Rialet.Pieters@nwu.ac.za; Henk.Bouwman@nwu.ac.za

An investigation of the bio-accumulation of dioxin-like substances in selected rivers of the Vaal Triangle region, Gauteng, South Africa

This study investigated the bio-accumulation of dioxins in aquatic environments of the Vaal Triangle. Sediment and fish tissue were collected from three rivers, extracted and subjected to the H4IIE-luc bio-assay. Bio-accumulation could not be confirmed, since the levels of dioxins in both matrices were too low to determine TCDD-equivalents.

Waterhulpbronne in Suid-Afrika is skaars en teen 2040 sal die behoefte na water waarskynlik die watervoorsiening oorskry. Dit is daarom noodsaaklik dat hierdie beperkte hulpbronne teen besoedelstowwe beskerm word, ook teen persisterende organiese besoedelstowwe (POBs). Die Stockholmkonvensie vir POBs stel dit ten doel om die vrystelling van hierdie besoedelstowwe te verminder en, waar moontlik, uiteindelik te elimineer. Die verdrag is geteken en bekragtig deur SuidAfrika en op 17 Mei 2004 het die Konvensie 'n internasionale wet geword. POBs is baie stabiele, hidrofobiese en lipofiliese organiese verbindings wat in biologiese weefsel kan ophoop of bioakkumuleer. Alhoewel konsentrasies van POBs aanvanklik laag mag wees, verhoog dit soos wat die besoedelstof in elke organisme van 'n voedselketting ophoop. As hoëvlakverbruikers in voedselkettings, is dit moontlik dat die mens aan hoë konsentrasies van POBs blootgestel word. Hierdie besoedelstowwe is dodelik in hoë konsentrasies, maar hul skadelikste effekte lê in hul kroniese toksisiteit. Toksiese effekte van POBs sluit onder andere kanker en defekte van die immuun-, voortplantings-, senuwee- en endokrienestelsel in. Alhoewel daar studies op pestisied POBs in Suid-Afrika gedoen is, is daar baie min bekend oor die dioksienagtige POBs. 'n Vorige ondersoek het aangetoon dat PCBs, dioksiene en furane teenwoordig is in akwatiese omgewings in SuidAfrika, met die hoogste vlakke van POBs in die Vaaldriehoekstreek. Hierdie studie fokus op dioksienagtige verbindings soos poligechloreerde bifeniele (PCB), poligechloreerde dibenso-paradioksiene (PCDD) en poligechloreerde dibenzofurane (PCDF). PCDD/Fs word as toevallige afvalprodukte in 'n verskeidenheid industriële en termiese prosesse, veral verbrandingsprosesse, gevorm maar PCBs word, daarenteen, vir industriële doeleindes vervaardig en is 'n bestanddeel in verf, plastiek en gom. Die doel van die studie was om bio-akkumulering van dioksienagtige POBs

Suid-Afrikaanse Tydskrif vir Natuurwetenskap en Tegnologie, Jaargang 26 No. 1: Maart 2007 
in sekere riviere van die Vaaldriehoekstreek te ondersoek, deur te fokus op dioksienvlakke in sediment en visweefsel. Hierdie matrikse is gekies, omdat POBs eerder met sediment en biota assosieer as om in water opgelos te wees. Een monsternemingsarea is vir elkeen van die volgende riviere gekies: Blesbokspruit, Kliprivier en Suikerbosrantrivier. Saamgestelde sediment- en vismonsters is versamel by elkeen van die lokaliteite. 'n Oorsigtelike visgesondheidsassesseringsindeksanalise is ook uitgevoer en die lewer, gonade en filette is deur disseksie verwyder. Die sediment- en visweefselmonsters is gevriesdroog voordat dit met die Soxhletapparaat geëkstraheer is met 'n drie-tot-een mengsel van dichloormetaan en heksaan. Die ekstrakte is gesuiwer met geaktiveerde koperkrulle, met suur gewas en gefraksioneer op grond van polariteit. Verdunningsreekse is gemaak van die rou ekstrak asook van elke fraksie. Die ekstrakte se dioksieninhoud is met die hulp van die H4IIE-luc biosiftingstoets bepaal. Die H4IIE selle is rotlewerkankerselle wat getransfekteer is met vuurvliegielusiferase. Die besoedelstowwe stimuleer lusiferasegeenuitdrukking en die konsentrasie daarvan word met ATP-aktiwiteit gemeet. Hierdie resultate is na TCDD-ekwivalente omgeskakel (TCDD:2,3,7,8-tetrachlorodibenso-para-dioksien). Die visgesondheidsindekse het getoon dat alle vis in 'n goeie toestand was. Alhoewel daar 'n beduidenis van POB-aktiwiteit by sommige monsters teenwoordig was, was die vlakke te laag om TCDD-ekwivalente akkuraat te bepaal. Potensiële bio-akkumuleringseffekte kon dus nie bevestig word nie.

\section{Morfologiese beskrywing van'n Diplozoon eksemplaar (Plathyhelminthes: Monogenea) wat op die kieue van Labeo rosae in die Olifantsriver gevind is}

\section{LD Woolley \& A Avenant-Oldewage}

Departement Dierkunde, Universiteit van Johannesburg, Posbus 524, Aucklandpark, 2006, SuidAfrika

Department of Zoology, University of Johannesburg, P.O. Box 524, Auckland Park, 2006, South Africa

lindsey@ridge.co.za; ao@na.rau.ac.za

\section{Identification of a Diplozoon species found on Labeo rosae in the Olifants River}

This ectoparasite was studied following standard and fluorescence staining. It has four pairs of clamps, a round ending intestine and eggs with coiled filaments, which make it distinguishable from the three other species found in South Africa.

Alle verteenwoordigers van familie Diplozoidae is ektoparasiete op die kieulamellae van visse in die familie Cyprinidae. Hierdie diergroep is uniek in die diereryk daarin dat twee individuele hermofroditiese larwes versmelt in permanente kopulasie. Slegs drie spesies van die takson is voorheen in Suid-Afrika aangeteken, naamlik 'n Diplozoon sp. wat Labeo umbratus parasiteer en 'n Paradiplozoon sp. wat op beide Labeobarbus aeneus en Labeobarbus kimberleyensis in die Vaalriviersisteem parasiteer. Die derde spesie, Neodiplozoon polycotyleus kom voor op verskeie Labeobarbus spesies in die Limpopo-provinsie. Hierdie studie konsentreer op ' $n$ vierde spesie wat op die kieue van Labeo rosae in die Olifantsrivier gevind is. Die parasiete is plat gefikseer in ysasyn-formaldehiedalkohol en gepreserveer in $70 \%$ etanol. Die morfologiese studie het die meting van die eksemplare met behulp van 'n Zeiss Axioplan 2-mikroskoop met Axiovision-sagteware 
(weergrawe 4.3) behels nadat totaalpreparate met Hören se trikroom en fluoreserende kleurmiddels behandel is. Daar is gevind dat die totale liggaamslengte wissel tussen $2.58-5.29 \mathrm{~mm}(\mathrm{n}=12)$ en dat die klampe ( $\mathrm{n}=123) 50 \mu \mathrm{m}$ lank en $90 \mu \mathrm{m}$ wyd is. Die bestudering van die totaalpreparate het getoon dat die eksemplare 'n ronde opisthaptor met vier pare klampe, 'n reguit blindeindigende intestinum, eiers met filamente, asook 'n unieke voortplantingstelsel besit. Fluoresensiemikroskopie het aan die lig gebring dat $\mathrm{N}$-asetielneuramiensuur, 'n sialiese suurresidu, teenwoordig is in die parasiet se integument en $N$ - asetielglukosamien, 'n kitienkomponent, in die gesklerotiseerde klampe. Die parasiet is geïdentifiseer as behorende tot die genus Diplozoon. Vergelykings tussen hierdie parasiet en die ander spesies wat voorheen in Suid-Afrika beskryf is, het daarop gedui dat dit 'n onbeskryfde spesie is. Hierdie onbekende parasiet verskil van die bekende spesies op grond van 'n kombinasie van die volgende morfologiese kenmerke: die klamp se sklerietmorfologie, 'n blindeindigende, buisvormige intestinum, eiers met filamente asook die afmetings van verskeie strukture.

\title{
Spesievariasie van kriobeskermers op wilde hoefdiere
}

\author{
B Corrigan ${ }^{1}$, GM Pieterse $^{1}$ \& P Bartels B $^{2}$ \\ ${ }^{1}$ Departement Dierkunde, Universiteit van Johannesburg, Posbus 524, Aucklandpark, 2006, Suid- \\ Afrika
}

Department of Zoology, University of Johannesburg, P.O. Box 524, Auckland Park, 2006, South Africa

${ }^{2}$ WBR, Biobank van NZG/NRF, Posbus 582, Pretoria, 0001

WBR, Biobank of NZG/NRF, P.O. Box 582, Pretoria, 0001

inap@uj.ac.za; paulb@wbrc.org.za

\section{Specie variation of cryoprotectants on wild ungulates}

The effect of cryoprotectants on epididymal sperm of domestic cattle, hartebees, koedoe and blue wildebeest was determined. Glycerol was found to be the most effective cryprotectant for domestic cattle and for the wild ungulates tested. Levulose was more effective for the vitality of the wild ungulate sperm.

Die bewaring van genetiese materiaal deur bevriesing van spermselle bied ' $n$ moontlike oplossing om skaars spesies van uitwissing te red. Min navorsing is tot op hede gedoen betreffende die bevriesing en bewaring van biomateriaal (spermselle, bloed en weefsel) van Suid-Afrikaanse wilde diere. Hierdie inligting is noodsaaklik om vriestegnieke te vestig om die mortaliteit van sperm so laag as moontlik te hou. Deur die bevriesing en bewaring van genetiese materiaal kan 'n bydrae gelewer word om wilde diere weer te hervestig in 'n natuurlike habitat. Die vernaamste funksie van kriobeskermers soos gliserol en dimetielsulfoksied (DMSO), is die binding van elektroliete. Hierdeur word verhoed dat chemiese komponente gekonsentreerd raak in die residuele ongevriesde intraen ekstrasellulêre vloeistowwe. Kriobeskermers bind voorts met watermolekules en beperk die vorming van yskristalle en help ook om gehidreerde proteïenmolekules te stabiliseer. Die vriespunt van intrasellulêre vloeistowwe word deur die kriobeskermer tot ongeveer $-45^{\circ} \mathrm{C}$ verlaag. ' $\mathrm{n}$ Kriobeskermer moet in staat wees om selle te penetreer om sodoende die styging in intrasellulêre elektrolietkonsentrasies te verhoed. Sekere makromolekules soos sukrose en polivinielpirolidoon wat nie in staat is om selle te penetreer nie, beskik oor die vermoë om selmembrane teen vriesbeskadiging te beskerm. Gliserol en DMSO word algemeen aangewend vir kriobewaring van 
sperme. Dit blyk dat die kriobewaring van alle wildspesies nie ewe suksesvol met bogenoemde kriobeskermers is nie. In hierdie studie is een niepenetrerende en twee penetrerende kriobeskermers getoets op die epididimale sperm van vier spesies, naamlike beeste (Bos taurus), hartebees (Alcelaphus buselaphus), koedoe (Tregalaphus strepsiceros) en die blouwildebees (Connochaetes taurinus). Motiliteitstoetse, ekwilibreringstyd, bevriesingstempo en tempo van ontdooiing van sperm in die epididimus van elke spesie is bestudeer en die morfohistologie van die testis van elke spesie is beskryf. Die resultate dui aan dat gliserol die effektiefste kriobeskermer vir beeste was, asook vir die progressiewe beweging van sperme vir al die bogenoemde hoefdiere. Levulose is meer effektief by die preservering van die persentasie lewendige selle van die toetsorganismes. Die resultate verkry in hierdie studie dra by tot die verdere ontwikkeling van kriobewaringstegnieke ten opsigte van wilde diere in Suid-Afrika.

\section{Taksonomiese ondersoek na die genus Eupolystoma (Monogenea: Polystomatidae)}

\section{A Delport \& LH du Preez}

Skool vir Omgewingswetenskappe en Ontwikkeling, Noordwes-Universiteit, Potchefstroom 2520, Suid-Afrika

School of Environmental Sciences and Development, North-West University, Potchefstroom, 2520, South Africa

drklhdp@puk.ac.za

\section{Taxonomic study of the genus Eupolystoma (Monogenea: Polystomatidae)}

As one of the 20 currently known polystome genera, Eupolystoma has been poorly studied. This parasite is only known from Africa and India. The measurement of marginal hooklets proved to be a valuable taxonomic characteristic for this genus.

Tot op hede is daar 20 verskillende genera binne die Polystomatidae bekend, waarvan Eupolystoma, Metapolystoma, Polystoma en Protopolystoma in Suid-Afrika aangetref word. Hierdie polistoomplatwurms is primêr parasities in paddas. Die genus Polystoma het 'n wêreldwye verspreiding, Metapolystoma en Protopolystoma is beperk tot Afrika terwyl Eupolystoma beperk is tot Afrika en Indië. Die genus Eupolystoma word onderverdeel in sewe spesies, naamlik Eupolystoma anterorchis uit Bufo pardalis, E. alluaudi uit Bufo gutturalis en E. vanasi in Schismaderma carens uit Afrika. Die twee spesies, E. chauhani uit 'n onbekende Bufo sp en $E$. rajai uit 'n onbekende Rana sp., is bekend uit Indië. Dan beskik ons oor materiaal van twee nuwe Eupolystoma spesies gevind in Bufo hoeschi van Namibië en Bufo garmani van Suid-Afrika. E. alluaudi is al gerapporteer uit gashere Bufo gutturalis, B. regularis, Pixicephalus adspersus en Nectophrynoides malcolmi. Afmetings van marginale hake dui daarop dat die E. alluaudi uit 'n kompleks van spesies bestaan. Binne die polistoom parasiete is daar groot intraspesievariasie en beperkte interspesievariasie. Afmetings van die harde skleriete waaronder die marginale hake van die parasiete is, is van groot taksonomiese belang. Vir die polistoomgenus Polystoma is die taksonomies mees beskrywende kombinasie van afmetings reeds bepaal deur alle moontlike afmetings wiskundig te ontleed en vir elke afmeting 'n klassifikasiewaarde te bepaal. Dit dien tans as protokol vir die beskrywing van nuwe parasiete. Hierdie protokol werk goed vir die genus Eupolystoma maar of dit die beste moontlike kombinasie afmetings is moet nog ondersoek word.

Suid-Afrikaanse Tydskrif vir Natuurwetenskap en Tegnologie, Jaargang 26 No. 1: Maart 2007 
Polistome is in die algemeen baie streng gasheerspesifiek en verskeie publikasies het al oor die onderwerp verskyn. Dit is bekend dat gasheerspesifisiteit by die genus Polystoma bepaal word deur die herkenning van slegs die eie gasheerpaddavis deur die parasietlarwe. In die geval van Eupolystoma infekteer die parasietlarwe die gasheer direk en word vermoed dat die meganisme was gesheerspesifisiteit bepaal verskillend sal wees.

\section{Die voedselvoorkeure van Schreiber se langvingervlermuis (Miniopterus schreibersii) in die Limpopo-provinsie}

\section{F NAude \& JFDurand}

Departement Dierkunde, Universiteit van Johannesburg, Posbus 524, Aucklandpark, 2006, SuidAfrika

Department of Zoology, University of Johannesburg, P.O. Box 524, Auckland Park, 2006, South Africa

fd@rau.ac.za

The food preferences of Schreiber's long-fingered bat (Miniopterus schreibersii) in the Limpopo Province

Miniopterus schreibersii has been on the Red Data List until recently. This small cave-dwelling bat is very sensitive to anthropogenic disturbances and has disappeared from large parts of its orginal documented range. It is not enough to conserve the caves which serve as the roosting and maternal breeding localities in order to conserve bats. Since bats feed outside the caves, it is important to conserve the habitats in the vicintiy of caves which sustain these bats in order to conserve them. M. schreibersii bats were sampled in the Limpopo Province and their stomach content was analysed in order to determine what food species are utilised by these bats. The results show that moths are by far the preferred food in autumn in the Makopane Valley near Polokwane.

Suid-Afrika spog met 'n uitsonderlike diversiteit van insekvretende vlermuise. Hierdie diversiteit word deur verskeie faktore bedreig. Om ons in staat te stel om hierdie diversiteit te beskerm, moet ons die delikate ekologie waarin vlermuise leef, verstaan. Die bewaring van grot-lewende vlermuise hang nie slegs af van die bewaring van die grotstelsels waarin hulle bly en kleintjies het nie, maar ook van die habitats buite die grot waarvandaan hulle hul kos verkry. Tien $M$. schreibersii vlermuise is in April 2006 in die Makopane Vallei tussen Polokwane en Makopane gevang. Nadat hulle met chloroform doodgemaak is, is die maaginhoud verwyder en in $70 \%$ etanol gepreserveer. Die maaginhoud is onder die mikroskoop ondersoek vir enige herkenbare liggaamsdele wat die identiteit van die insekte sou bekend maak. Miniopterus schreibersii (Familie: Vespertilionidae) kan tot 13 jaar lank leef. Die voedselvoorkeure van hierdie spesie is bestudeer deur tien individue by Ficus Grot naby Mokopane (Potgietersrus) in die Limpopo-provinsie te vang en hulle maaginhoud te ondersoek. M. schreibersii het 'n groot broeikolonie in hierdie grotte vanaf lente tot herfs. 'n Groot verskeidenheid insekfragmente is gevind. Alhoewel dit moeilik was om die fragmente te identifiseer, omdat baie diagnostiese strukture tydens die voedingsproses verlore gegaan het, was dit moontlik om die oorblyfsels van die Orde Lepidoptera en Hemiptera te identifiseer. Alhoewel die literatuur bevestig dat M.schreibersii op insekte van die Ordes Lepidoptera, Hemiptera, Coleoptera en Diptera voed, kom daar verreweg meer motte as enige ander insekte in die dieet van $M$. schreibersii in die

Suid-Afrikaanse Tydskrif vir Natuurwetenskap en Tegnologie, Jaargang 26 No. 1: Maart 2007 
Makopane-vallei in die herfs voor. Ons kan dus aflei dat hierdie vlermuise afhanklik is van hierdie voedselbron gedurende die herfsmaande in die Makopane-vallei. Indien insekgif deur die omliggende boerderye gebruik word om motte te bestry, kan dit die oorlewingsvermoë van hierdie vlermuisspesie in die gebied bedreig.

\section{Seisoenale veranderinge in die verspreiding en aktiwiteite van amfibieë in die Vredefortkoepel-bewaringsarea}

\section{W Conradie, C Weldon, KG Smith \& LH du Preez}

Skool vir Omgewingswetenskappe en Ontwikkeling, Noordwes-Universiteit, Potchefstroom 2520, Suid-Afrika

School of Environmental Sciences and Development, North-West University, Potchefstroom, 2520, South Africa

drkwc@puk.ac.za; drkcw@puk.ac.za; drkkgs@puk.ac.za; drklhdp@puk.ac.za

\section{Diversity and conservation of the amphibians in the Vredefort Dome World Heritage Site}

The aim of the study was to determine the anuran diversity of the Vredefort World Heritage Site. This was done by a year long monitoring of the area, listening to male chorus, visual encounters and sampling of tadpoles. Thirteen species were recorded for the area.

Op 14 Julie 2005 is die Vredefortkoepel tot die $7^{\text {de }}$ Wêrelderfenisgebied van Suid-Afrika verklaar. Vandag word algemeen aanvaar dat dit die oudste en grootste meteoriet-impakkrater in die wêreld is. Dit is ongeveer 2020 miljoen jaar gelede gevorm toe 'n meteoriet so groot soos Tafelberg die aarde getref het en 'n krater van $250 \mathrm{~km}$ in deursnee en $40 \mathrm{~km}$ diep gevorm. Vandag is net die geërodeerde oorblyfsels sigbaar noord-wes van die impakkrater. Die geologie en geografie van die area is goed bestudeer maar relatief min is bekend van die ekologie en diversiteit van diere in die area. Die doel van die huidige studie was om die spesiediversiteit, seisoenale aktiwiteitpatrone, broeigedrag en interaksies van amfibieë te bepaal, asook om die status van die amfibiese chytridswam, Batrachochytrium dentrobatidis in die Vredefortkoepel te bepaal. Historiese data versamel gedurende die Suid-Afrikaanse Padda-Atlasprojek (2004) en ander navorsing toon dat die volgende spesies teenwoordig was: Ametiaa angolensis, A. fuscigula, Breviceps adspersus, Amietophrynuso gutturalis, A.. rangeri, A.. poweri, Cacosternum boettgeri, Kassina senegalensis, Phrynobatrachus natalensis, Pyxicephalus adspersus, Schismaderma carens, Semnodactylus weallii, Strongylopus fasciatus, Tomopterna cryptotis en Xenopus laevis. Die studie-area beslaan slegs twee kwartgraad selle en daarom is besluit om die studie-area in matrikse te verdeel om sodoende 'n beter resolusie te verkry. Paddas is geïdentifiseer op grond van die roepe asook deur eksemplare fisies te ondersoek. Paddavisse is ook gebruik vir identifikasie en om die teenwoordigheid van die amfibiese chytrid te bepaal. Monitering het oor 'n tydperk van een jaar gestrek. Met uitsondering van Phrynobatrachus natalensis, Pyxicephalus adspersus en Semnodactylus weallii is al die spesies hierbo gelys, weer gevind en Tomopterna natalensis is vir die eerste keer in die area aangeteken. Die amfibiese chytrid-swam is slegs in A. angolensis paddavisse gevind in die maande van Augustus tot November. Hierdie besmetting hou egter nie tans 'n gevaar in vir die voortbestaan van die spesie in die betrokke area nie. 


\section{'n Vergelykende studie van die pineale kompleks, pariëtale oog, optiese lobbe en oë van twee skinkspesies, naamlik die oppervlakwonende Mabuya striata en die grawende akkedis, Acontophiops lineatus}

J Jardine, PC de Lange-Jacobs \& JF Durand.

Departement Dierkunde, Universiteit van Johannesburg, Posbus 524, Aucklandpark, 2006, SuidAfrika

Department of Zoology, University of Johannesburg, P.O. Box 524, Auckland Park, 2006, South Africa

pdlj@na.rau.ac.za

A comparative study of the pineal complex, parietal eye, optic lobes and eyes of two skink species, the surface-dwelling Mabuya striata and the burrowing skink Acontophiops lineatus Fossorial reptiles show a tendency towards the reduction of limbs and certain sense organs, particularly the eyes and ears. Skinks display a range of adaptations ranging from the plesiomorph design with fully functional legs, eyes and ears to forms that are legless, earless and blind. The focus of this project was to determine whether the optic lobes and pineal organ, which also depends on the availability of light, are as reduced as the eyes in the burrowing skink Acontophios lineatus. The study shows that there is a considerable reduction in the size and structure of the pineal complex and optic lobes which match the reduction of the eyes in $\underline{A}$. lineatus compared to the same structures in the surface-dwelling Mabuya striata.

Die doel van hierdie studie was om die effek van 'n grawende lewenswyse op die senustelsel van die skink te bepaal. Dit is lank reeds bekend dat die oë, ore en bene van grawende skinke resessief word en selfs verdwyn. Elke variasie van die reduksie van die oog- en oorapparaat en aanhangsels kom in skinke voor en maak hulle dus die ideale groep om die evolusionêre aanpassing tot 'n grawende lewenswyse te bestudeer. Sekere skinke soos Mabuya striata is oppervlakbewonend en het volledig funksionerende oë en ore, ander soos Acontophiops lineatus se oë en ore is sterk gereduseer, ander weer het geen oë of ore nie. Twee voorbeelde van elk van Mabuya striata en Acontophiops lineatus is vir hierdie studie uit die versameling van die Transvaal-Museum verkry. Die koppe van elke voorbeeld was geamputeer en na voorbereiding om dit te dekalsifiseer en te preserveer, is dit in was ingebed. Seriaalsneë is met behulp van 'n mikrotoom gemaak waarvan mikroskoopplaatjies gemaak is. Vir hierdie studie is Mabuya striata, 'n oppervlakwonende spesie wat goed aangepas is vir 'n predatoriese lewenswyse (dit wil sê sterk ledemate en uitstekende sig), en Acontophiops lineatus, die grawende akkedis (sonder uitwendige oë of ledemate), met mekaar vergelyk. Die pineale kompleks is noodsaaklik vir die funksionering van endokriene sisteme, seksuele periodisiteit en sirkardiese ritmes. Die pariëtale oog reageer op direkte sonlig en meet veranderinge in die elektrofisiologie van lig wat noodsaaklik is vir die funksionering van spesies. Die pariëtale oog word vir termoregulering aangewend aangesien hierdie poikilotermiese diere lig en skaduwee aanwend vir energiehandhawing. Oppervlakwonende spesies het goed ontwikkelde oë met uitstekende driedimensionele sig. Die oë van die grawende spesies is baie gereduseer en bedek deur 'n skub vir beskerming teen wrywing in die grond. Hierdie gereduseerde organe kan moontlik nog tot ' $n$ mate ligsensitief wees, maar beweging en kleur sal nie waargeneem kan word nie. Oor die algemeen bestaan die optiese lobbe uit senuweeweefsel wat die funksie van die oë beheer en daar is ' $n$ korrelasie tussen die grootte daarvan en die belangrikheid van sig in die dier. Die morfologie

Suid-Afrikaanse Tydskrif vir Natuurwetenskap en Tegnologie, Jaargang 26 No. 1: Maart 2007 
van die pineale kompleks, pariëtale oog, optiese lobbe, optiese senuwee en oë van beide spesies is vergelyk deur die voorbereiding en bestudering van seriesneë van die koparea. Daar is 'n duidelike aanduiding in die organe van $M$. striata en A. lineatus, dat habitat 'n groot invloed het op die morfologie en adaptasie daarvan, met gevolglike evolusionêre implikasies. Oppervlakbewoning vereis dat die dier funksionele oë en pineale kompleks besit om te oorleef. Hierdie organe is uiteraard ligsensitief en sal dus nie ten volle funksioneel in donker habitats kan wees nie. Hierdie aanname is bevestig deur die vergelyking van die ligsensitiewe orgaanstelsels in die twee skinke. Die oog, pineale orgaan en die optiese lobbe van die grawende skink is opmerklik gereduseer in vergeleke met dié van die oppervlakbewonende skink.

\section{Neerslag van kalksteenstof lei tot die inhibisie van fotosintese in woestynplantegroei}

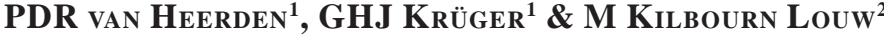

${ }^{1}$ Skool vir Omgewingswetenskappe en Ontwikkeling, Afdeling Plantkunde, NoordwesUniversiteit, Potchefstroom, 2520

School of Environmental Sciences and Development, Plant Studies, North-West University, Potchefstroom, 2520

${ }^{2}$ Skorpion Zinc Project Environmental Scientist, Rivonia, 2128

plbpdrvh@puk.ac.za; plbghjk@puk.ac.za; michelekl@mweb.co.za

\section{Limestone dust deposition inhibits photosynthesis in desert vegetation}

The effects of limestone dust deposition were investigated in a succulent shrub (Zygophyllum prismatocarpum) at a limestone quarry near Skorpion Zinc mine (Namibia) by means of chlorophyll a fluorescence. Limestone dust deposition caused inhibition of $\mathrm{CO}_{2}$ assimilation. Dynamic recovery, accelerated by rainfall, occurred after termination of limestone extraction at the quarry.

Die nadelige effekte van kalksteenstof op plantegroei in die nabyheid van industriële gebiede is lank reeds bekend. Vanweë die beperkte antropogeniese aktiwiteit in die meeste woestyne, is die invloed van kalksteenstofneerslag op plantegroei in woestynekosisteme nog nooit ondersoek nie. Blootstelling van woestynplante aan kalksteenstof kan verskeie nadelige effekte veroorsaak. Eerstens, kalksteenstofneerslag kan lei tot toenames in blaartemperatuur as gevolg van verhoogde vasvanging van infrarooistraling deur stofdeeltjies op die blaaroppervlaktes. Tweedens, kalksteenstofdeeltjies kan die stomas blokkeer wat tot verlaagde transpirasietempo's en verdere verhoging in blaartemperatuur kan aanleiding gee. Derdens kan kalksteenstofdeeltjies in sekere gevalle inmeng met normale stomawerking wat volkome stomasluiting gedurende die nag kan verhinder en tot verhoogde waterverlies aanleiding gee. In 'n woestynomgewing, waar lae reënval en hoë temperature algemeen is, kan bogenoemde effekte ernstige implikasies vir die oorlewing van plantegroei inhou. Verder is kalksteenstof uiters alkalies en kan dit die kutikulabedekking van blare verweer en lei tot chlorofilafbraak indien dit toegang tot blare sou verkry. In hierdie studie is die effek van kalksteenstofneerslag in 'n Zygophyllum prismatocarpum E. Mey. Ex. Sond. populasie in die Sperrgebiet area van die Namibwoestyn by 'n steengroef in die nabyheid van Skorpion Zinc myn ondersoek. Die ondersoek is vanaf Mei 2003 tot April 2004 uitgevoer op plante wat op verskillende afstande van die kalksteengroef geleë was. Plante op afstande van 50 m, 200 m en 600 
$\mathrm{m}$ vanaf die kalksteengroef is geselekteer op grond van sigbare verskille in stofbedekking. Plante $50 \mathrm{~m}$ weg van die kalksteengroef was gekenmerk deur swaar stofbedekking, terwyl plante $200 \mathrm{~m}$ en $600 \mathrm{~m}$ weg, onderskeidelik slegs matige en geringe stofbedekking vertoon het. Skandeerelektronmikroskopie (SEM) is aangewend om die stofbedekking op blare te ondersoek. Anorganiese elementanalise van stofdeeltjies op blare is met behulp van elektrondigtheid-spektrometrie (EDS) uitgevoer. Chlorofil-fluoressensie, chlorofilinhoud, fotosintetiese gaswisseling en blaarwaterpotensiaalmetings is gebruik om die effek van kalksteenstofbedekking op die fisiologie van die plante te kwantifiseer. SEM en EDS analise het onderskeidelik aangetoon dat die blare van plante in die nabyheid van die kalksteengroef $(50 \mathrm{~m})$ ten volle bedek was met stofdeeltjies en dat die elementsamestelling van die stof ooreengestem het met dié van kalksteen. In teenstelling met die plante naby die kalksteengroef $(50-200 \mathrm{~m})$ was plante $600 \mathrm{~m}$ weg feitlik stofvry en kon die unieke oppervlakskulptuur van die blare duidelik waargeneem word. Chlorofil-fluoressensiemetings het duidelik aangetoon hoe die primêre reaksies van fotosintese deur kalksteenstofbedekking geïnhibeer is en hoe die graad van inhibisie verminder het met toenemende afstand weg van die kalksteengroef af. Hierdie metings het ook die teenwoordigheid van hittestremming in die plante $50 \mathrm{~m}$ weg van die kalksteengroef aangetoon. Kalksteenstofbedekking het verder gelei tot afnames in blaararea, chlorofilinhoud en fotosintesetempos. Nadat ontginning van kalksteen by die steengroef gestaak is, het die simptome van stofbedekking geleidelik oor etlike maande verdwyn en kon opmerklike stimulering van nuwe blaargroei en verhoging in chlorofilinhoud waargeneem word. Die herstel van plante is verder bevorder deur winterreënval, wat nie net die stofbedekking van blare verwyder het nie, maar ook kapasiteit vir nuwe groei verskaf het. Hierdie studie het nuwe lig gewerp op die effek van kalksteenstofbedekking op plante en is uniek omdat dit uitgevoer is in 'n woestynomgewing waar reënval 'n sleutelfasiliteerder van herstelprosesse was.

\section{Die bestudering van fenotipiese en genotipiese eienskappe van sekere psigrotrofiese voedselgedraagde bakterië̈}

\section{A JaCoby \& H de BeER}

Eenheid vir Toegepaste Voedselwetenskap en -Biotegnologie. Skool vir Landbou en Omgewingswetenskappe, Sentrale Universiteit vir Tegnologie, Bloemfontein, 9301

Applied Food Science and Biotechnology, School of Agricultural and Environmental Sciences, Central University of Technology, Bloemfontein, 9301

ajacoby@cut.ac.za; hdebeer@cut.ac.za

Assessment of phenotypic and genotypic characteristics of food borne psychrotrophic bacteria The purpose of this study was to compare whole cell protein profiles, generated by SDS-PAGE. The effect of different incubation temperatures on the profiles was also investigated. For the characterization and analysis standard protocol was followed. Clear differences in structures were found between the bacteria.

Psigrotrofe-organismes het die vermoë om by temperature tussen $0^{\circ}$ en $7^{\circ} \mathrm{C}$ te groei. Hierdie organismes is dikwels verantwoordelik vir die bederf van voedsel wat in die yskas geberg word. Bederf van vleis, vis, pluimvee, melk en groente word veral deur ongewenste geure gekenmerk. Van die vroegste tye af het die mens al probeer om voedselbederf teë te werk. Met die uitvinding van die yskas is daar geglo dat voedselbederf iets van die verlede sal wees, maar bakterieë is egter baie

Suid-Afrikaanse Tydskrif vir Natuurwetenskap en Tegnologie, Jaargang 26 No. 1: Maart 2007 
aanpasbaar. As bakterieë eers in 'n nuwe omgewing aangepas het, kan dit baie vinnig vermeerder. Inligting oor die spesifieke meganisme van bederf, deur psigrotrofe-bakterieë is beperk en die meeste literatuur handel oor die isolasie van die bakterieë. Navorsing oor die biochemiese reaksies waarby spesifieke spesies betrokke is of molekulêre metodes wat gebruik kan word vir die bestudering van die organismes, bied nuwe uitdagings vir voedselmikrobiologie. Die interaksie tussen die bakterieë en voedsel word nie duidelik beskryf nie en identifisering van metaboliete, wat deur die organismes tydens opberging gevorm word, kan moontlik 'n waardevolle bydrae tot rakleeftydbepalings maak. Die doel van hierdie studie is om met behulp van proteïen-gelelektroforese die proteïenprofiele van verskillende psigrotrofe-bakterieë te vergelyk. Verder word die invloed van verskillende inkubasietemperature op die proteïnprofiele van die verskillende bakterieë ook bestudeer. Verbeterde tegnieke, veral op molekulêre vlak, het tot gevolg gehad dat veranderinge in die klassifikasie van sekere bakteriegroepe oor die laaste paar jaar plaasgevind het. Drie nuwe Gram-negatiewe, geel gepigmenteerde kolonies is gedurende die afgelope paar jaar in die Vrystaat geïsoleer en benoem. Hierdie drie: Chryseobacterium joostei, C. piscium en $C$. vrystaatense is deel van ' $\mathrm{n}$ nuwe genus wat in die Flavobacteriaceae-familie beskryf is. In teenstelling met ander organismes wat in die genus beskryf is, is die organismes uit rou vis en hoender geïsoleer. Karakterisering en analise van proteïen word met 'n standaard prosedure gedoen. Dit bestaan uit die isolering van die bakterieë, ekstraksie en skeiding van die heelselproteïne. Die generering van 'n dendrogram met behulp van spesifieke sagteware word gedoen deurdat proteïenbande met mekaar en 'n standaard vergelyk word. Hierdie bestudering van die proteïene toon duidelike verskille tussen die verskillende bakterieë aan. Die poli-akrielamied-gel-elektroforese (PAGE) is 'n vinnige, koste-effektiewe metode. Dit is herhaalbaar vir die kwantifisering, vergelyking en karakterisering van die proteïne van die verskillende lyne. Die vertikale gelsisteem kan twee gelle gelyktydig hanteer en veertien proteïenekstrakte en ses kontroles of standaarde kan op een gel gelaai word. Hierdie metode kan dus baie suksesvol vir die bepaling van diversiteit tussen verskillende mikrobepopulasies aangewend word.

\section{Anura as biologiese indikator by ongerehabiliteerde uraanmyne}

\section{H Groenewald, HJB Butler \& N Scholtz}

Departement Dierkunde en Entomologie, Departement Geologie, Universiteit van die Vrystaat, Bloemfontein, 9300

Department of Zoology and Entomology, Department of Geology, University of the Free Sate, Bloemfontein, 9300

GroenewaldH.sci@mail.uovs.ac.za; ButlerHJ.sci@mail.uovs.ac.za ; ScholtzN.sci@mail.uovs.ac.za

\section{Anura as biological indicator at uranium mines}

Xenopus laevis were obtained at a uranium mine with high uranium and molybdenumconcentrations. By using an ICP-MS, high levels of these elements were found in different tissue types. Higher larvae-mortalities occurred at the group consisting of contaminated females.

Ondanks gebruik van Anura as goeie biologiese indikator, kom Xenopus leavis natuurlik voor in waterliggame met verhoogde uraan en molibdeenkonsentrasies in die sentrale Karoo. Alhoewel hierdie elemente gevare inhou vir lewende organismes, kon geen sigbare newe-effekte waargeneem 
word by hierdie diere nie. Ten einde die effek te bepaal wat uraan en sekondêre produkte daarvan op histologiese vlak asook die voortplantingsukses van paddas het, is Zenopus laevis met behulp van 'n lokval in 'n oopgroefuraanmyn versamel. Histologiese snitte is van alle moontlike weefseltipes gemaak terwyl die konsentrasie van uraan, molibdeen asook lood deur middel van 'n massa-spektrofotometer verkry is. Ten einde die effek van uraan op die voortplanting van die betrokke spesie te bepaal, is paring kunsmatig deur middel van gonadotropien geïnduseer. Besmette individue van beide geslagte is onderskeidelik met besmette sowel as onbesmette individue van ander geslagte afgesonder terwyl 'n kontrolegroep bestaan het uit onbesmette mannetjies en wyfies. Eierlegging, kliewingstadia en larwale ontwikkeling is deurgaans genoteer. Uitermatig hoë hoeveelheid uraan is in die bloed, lewer, been en gonades aangetref, terwyl molibdeen hoofsaaklik in lewer en gonadeweefsel geakkumuleer het. Ondanks hierdie hoë vlakke van besmetting, kon geen nekrose op histologiese vlak waargeneem word nie. Wat voortplanting betref, het uraanbesmette wyfies in die algemeen minder eiers gelê terwyl dit ook die groep was waar die hoogste mortaliteite onder larwes voorgekom het. Geen waarneembare verskil kon tussen die hoeveelheid eiers of larwale mortaliteit gevind word waar besmette sowel as onbesmette mannetjies by onbesmette wyfies geplaas is nie. Dit wil dus voorkom asof die betrokke elemente 'n groter invloed het op die reproduksievermoë van Xenopus-wyfies.

\section{Die effek van uraanmyne op kleinsoogdierpopulasies}

\section{H Grünewald ${ }^{1}$, HJB Butler ${ }^{1} \&$ N Scholtz $^{2}$}

Departement Dierkunde en Entomologie ${ }^{1}$, Departement Geologie ${ }^{2}$, Universiteit van die Vrystaat, Bloemfontein, 9300

Department of Zoology and Entomology, Department of Geology, University of the Free State, Bloemfontein, 9300

hanri@cleanstream.co.za; ButlerHJ.sci@mail.uovs.ac.za; ScholtzN.sci@mail.uovs.ac.za

\section{The effect of uranium mines on small mammal populations}

As uranium mining is increasing, it is important to know the effects this radio-active metal has on mammals. Gathering of small mammals was followed by mass-spectrophotometer analysis. Different concentrations of uranium, molybdenum and lead accumulated in different mammal tissue.

Alternatiewe vir die opwekking van elektrisiteit, in die plek van fossielbrandstof, is op die lang duur onvermydelik. Die gebruik van uraan vir kernkragopwekking maak wêreldwyd opspraak. Uraan is 'n element wat natuurlik teenwoordig is in grond, gesteentes, oppervlak en grondwater asook in plantmateriaal. Uraan en sy afbouprodukte is gevaarlik vir lewende organismes indien die element deur die liggaam ingeneem word. Min inligting is egter beskikbaar oor die chemiese en radiotoksiese effek van uraan op ekosisteme. Ten einde die effek van uraan op ekosisteme te bepaal, is die diversiteit van klein soogdiertjies in die nabye omgewing van ' $n$ ongerehabiliteerde uraanmyn in die sentrale Karoo met behulp van muisvalle bepaal. Die voorkoms, al dan nie, van radon is in openinge tussen uraanertshope, waar klipdassies (Procavia capensis) natuurlik voorkom, bepaal. Verskeie weefseltipes is by alle betrokke spesies versamel en die bio-akkumulering van radioaktiewe elemente daarin is met behulp van 'n massa-spektrofotometer bepaal. Wat spesieverskeidenheid betref, het verteenwoordigers van die families Muridae, Macroscelididae, Soricidae en Procaviidae voorgekom. Alhoewel tekens van nekrose in van die weefsel voorgekom het, kon

Suid-Afrikaanse Tydskrif vir Natuurwetenskap en Tegnologie, Jaargang 26 No. 1: Maart 2007 
geen sigbare effek van blootstelling aan uraan op enige van die versamelde individue gesien word nie. Terwyl daar gepubliseerde materiaal bestaan wat bewys dat hoë vlakke van radiasie gevaarlik is vir biologiese materiaal, is daar ook gedokumenteerde studies wat bewys dat biologiese materiaal gestimuleer word deur lae vlakke van radiasie. Die voorkoms van uraan, molibdeen en lood varieer in die verskeie weefseltipes.

\section{Die effek van akute koperblootstelling op die biologie van die moddervis (Labeo capensis) en die grootbekbaars (Micropteris salmoides) in harde water}

\section{WJ van Aardt \& M Hough}

Skool vir Omgewingswetenskappe en Ontwikkeling, Noordwes-Universiteit, Potchefstroom, 2025 School of Environmental Sciences and Development, North-West University, Potchefstroom, 2520

DRKWJVA@puknet.puk.ac.za

The effects of acute copper exposure on the biology of the mudfish (Labeo capensis) and the large mouth bass (Micropteris salmoides) in hard water.

Sediment samples together with fish tissue were collected at the three dams situated in the Mooi River near a gold mine area. The oxygen consumption rate $\left(\mathrm{MO}_{2}\right)$ was also measured. Copper accumulated five times more in the liver compared with the gonades. Fish exposed to $10 \mathrm{mg} \mathrm{Cu}$.$\mathrm{A}^{-1}$ for 2 hours decrease their $\mathrm{MO}_{2}$ significantly from $5.17 \pm 0.32 \mathrm{mmol} \mathrm{O}_{2} \cdot{ }^{-t^{-1}} \cdot \mathrm{kg}^{-1} \mathrm{hour}^{-1}$ for the

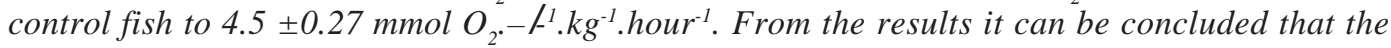
imported large mouth bass is biologically more resistant against copper compared to the endemic mudfish

Sedimentmonsters asook visweefsels vanaf drie damme naby die goudmyne in die Mooirivier opvang gebied is vir $\mathrm{Cu}$ geanaliseer. Verder is die effek van koper op die suurstofverbruik en die kieufrekwensie in die laboratorium getoets by Labeo capensis en by Micropteris salmoides, 'n uitheemse vis. Koperkonsentrasies van damsediment tot $5 \mathrm{~cm}$ diep by Klerkskraaldam ( $22.2 \mathrm{mg}$ Cu. $\left.\mathrm{kg}^{-1}\right)$, Boskopdam (14.1 mg Cu. $\mathrm{kg}^{-1}$ ) en Potchefstroomdam (21.7 mg Cu. $\mathrm{kg}^{-1}$ ) is meer as die aanvaarde risikowaardes soos neergelê deur die Suid-Afrikaanse riglyne. Die laagste [Cu] word in die bloed, ovaria en testes van die twee visspesies by al drie die damme gevind. Koper akkumuleer tot vyf keer meer $\left(110.1 \pm 17.8 \mathrm{mg} \mathrm{Cu} . \mathrm{kg}^{-1}\right.$ droë lewermassa $)$ in lewer in vergelyking met die gonades. As visse aan $10 \mathrm{mg} \mathrm{Cu} .-^{-1}$ vir 120 minute blootgestel word of vir 96 uur aan $1 \mathrm{mg} \mathrm{Cu} \cdot-^{-1}$ akkumuleer $\mathrm{Cu}$ hoofsaaklik in die kieue en lewer. Tydens die 120 minute blootstellingstyd aan $\mathrm{Cu}$ neem die operkulêre frekwensie by beide visspesies toe van $80 \pm 5.7$ siklusse tot meer as $100 \pm 5.8$ siklusse per minuut. Na 90 minute neem die operkulêre frekwensie egter af by die moddervis tot nul en die vis vrek, maar nie by die grootbekbaars nie. Die suurstofverbruikskoers $\left(\notin \mathrm{O}_{2}\right)$ van L. capensis, na twee uur blootstelling aan $10 \mathrm{mg} \mathrm{Cu} \cdot-^{-1}$, verminder betekenisvol van $5.17 \pm 0.32 \mathrm{mmol} \mathrm{O}_{2} \cdot-^{-1} \cdot \mathrm{kg}^{-}$ ${ }^{1}$ uur $^{-1}$ vir die kontrolevisse tot $4.5 \pm 0.27 \mathrm{mmol} \mathrm{O}_{2} \cdot-^{-1} \cdot \mathrm{kg}^{-1} \cdot \mathrm{uur}^{-1}$. Dieselfde vermindering in die $\notin \mathrm{O}_{2}$ is ook vir $M$. salmoides gevind. $\mathrm{Na} 96$ uur blootstelling aan $1 \mathrm{mg} \mathrm{Cu}$ verminder die $\notin \mathrm{O}_{2}$ vir beide visspesies betekenisvol van $5.17 \pm 0.32$ na $2.9 \pm 0.3 \mathrm{mmol}_{2}{ }^{-l^{-1}} \cdot \mathrm{kg}^{-1} \cdot$ uur $^{-1}$. Uit die resultate blyk die volgende. 1) Die ingevoerde grootbekbaars is biologies meer weerstandbiedend teen akute $\mathrm{Cu}-$ konsentrasies as die inheemse moddervis. 2) Vir beide visspesies akkumuleer $\mathrm{Cu}$ hoofsaaklik in die 
lewer gevolg deur die kieue en niere. 3) [Cu] in die sediment, wat meer as $20 \mathrm{mg} \mathrm{Cu} \cdot \mathrm{kg}^{-1}$ droë sediment beloop, $\mathrm{kan}$ in die water oplos as die $\mathrm{pH}$ van die water laer as 5.0 eenhede daal. 4). In harde water is $\mathrm{Cu}$ omtrent 10 keer meer toksies as dit vergelyk word met soortgelyke studies vir lood en kadmium. 